\title{
The dynamic of the annual carbon allocation to wood in European tree species is consistent with a combined source-sink limitation of growth: implications for modelling
}

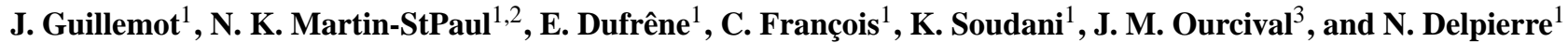 \\ ${ }^{1}$ Laboratoire Ecologie, Systématique et Evolution, Université Paris Sud, CNRS, AgroParisTech, UMR8079, \\ 91405 Orsay, France \\ ${ }^{2}$ Ecologie des Forêts Méditerranéennes, INRA, UR629, 84914 Avignon, France \\ ${ }^{3}$ CEFE, CNRS, Université de Montpellier, Université Paul-Valéry Montpellier, EPHE, UMR5175, \\ 34293 Montpellier, France
}

Correspondence to: J. Guillemot (joannes.guillemot@gmail.com)

Received: 13 January 2015 - Published in Biogeosciences Discuss.: 2 February 2015

Revised: 16 April 2015 - Accepted: 17 April 2015 - Published: 11 May 2015

\begin{abstract}
The extent to which wood growth is limited by carbon (C) supply (i.e. source control) or by cambial activity (i.e. sink control) will strongly determine the responses of trees to global changes. Nevertheless, the physiological processes that are responsible for limiting forest growth are still a matter of debate. The aim of this study was to evaluate the key determinants of the annual $\mathrm{C}$ allocation to wood along large soil and climate regional gradients over France. The study was conducted for five tree species representative of the main European forest biomes (Fagus sylvatica, Quercus petraea, Quercus ilex, Quercus robur and Picea abies).

The drivers of stand biomass growth were assessed on both inter-site and inter-annual scales. Our data set comprised field measurements performed at 49 sites (931 siteyears) that included biometric measurements and a variety of stand characteristics (e.g. soil water holding capacity, leaf area index). It was complemented with process-based simulations when possible explanatory variables could not be directly measured (e.g. annual and seasonal tree $\mathrm{C}$ balance, bioclimatic water stress indices). Specifically, the relative influences of tree $\mathrm{C}$ balance (source control), direct environmental control (water and temperature controls of sink activity) and allocation adjustments related to age, past climate conditions, competition intensity and soil nutrient availability on growth were quantified.

The inter-site variability in the stand $\mathrm{C}$ allocation to wood was predominantly driven by age-related decline. The direct
\end{abstract}

effects of temperature and water stress on sink activity (i.e. effects independent from their effects on the $\mathrm{C}$ supply) exerted a strong influence on the annual stand wood growth in all of the species considered, including deciduous temperate species. The lagged effect of the past environmental conditions (e.g. the previous year's water stress and low $\mathrm{C}$ uptake) significantly affected the annual $\mathrm{C}$ allocation to wood. The $\mathrm{C}$ supply appeared to strongly limit growth only in temperate deciduous species.

We provide an evaluation of the spatio-temporal dynamics of the annual $\mathrm{C}$ allocation to wood in French forests. Our study supports the premise that the growth of European tree species is subject to complex control processes that include both source and sink limitations. The relative influences of the growth drivers strongly vary with time and across spatial ecological gradients. We suggest a straightforward modelling framework with which to implement these combined forest growth limitations into terrestrial biosphere models.

\section{Introduction}

Forests play a critical role in the global carbon (C) cycle. Inventory-based estimates indicate that established forests have been a persistent carbon sink for decades, sequestering almost $30 \%$ of the world's total anthropogenic C emissions between 1990 and 2007 (Pan et al., 2011). The fate 
of the sequestered $\mathrm{C}$ is highly dependent on the $\mathrm{C}$ dynamic in trees, which determines the residence time of $\mathrm{C}$ in forest ecosystems. Despite its importance for the future terrestrial C sink (Carvalhais et al., 2014; Friend et al., 2013), the partitioning of $\mathrm{C}$ among tree organs and ecosystem respiration remains poorly understood (Brüggemann et al., 2011). In particular, there has been a considerable amount of debate regarding the physiological mechanisms that drive the increment of the forest woody biomass (Palacio et al., 2014; Wiley and Helliker, 2012). The fraction of assimilated C stored in woody biomass can be inferred by combining biometric measurements with estimates of the $\mathrm{C}$ exchange between the ecosystem and atmosphere, based on the eddy-covariance (EC) technique (Babst et al., 2014; Litton et al., 2007; Wolf et al., 2011). Global meta-analyses (that included data from various biomes and species) have revealed a strong correlation between the observed gross primary production (GPP) and the woody biomass increment (Litton et al., 2007; Zha et al., 2013). Accordingly, growth has long been thought to be $\mathrm{C}$ limited, because of the hypothesized causal link between C supply and growth (i.e. source control; Sala et al., 2012). The environmental factors that have been reported to affect growth (soil water content, temperature, nutrient content, light and $\mathrm{CO}_{2}$ ) were therefore supposed to operate through their effects on photosynthesis and respiration fluxes. This $\mathrm{C}$-centric paradigm underlies most of the $\mathrm{C}$ allocation rules formalized in the terrestrial biosphere models (TBMs) that are currently used to evaluate the effects of global changes on forests (Clark et al., 2011; Dufrêne et al., 2005; De Kauwe et al., 2014; Krinner et al., 2005; Sitch et al., 2003).

Source control of wood growth is a mechanism that has been questioned by several authors, who argue that cambial activity is more sensitive than $\mathrm{C}$ assimilation to several environmental stressors (Fatichi et al., 2014). In particular, the decrease in cell turgor that occurs because of water stress strongly affects cell division and expansion (Woodruff and Meinzer, 2011) before there is any strong reduction in the gas exchange (Muller et al., 2011; Tardieu et al., 2011). Similarly, cell division is more sensitive than photosynthesis to low temperatures (Körner, 2008). The onset of cambial activity is also known to be highly responsive to temperature (Delpierre et al., 2015; Kudo et al., 2014; Lempereur et al., 2015; Rossi et al., 2011) and, in turn, may partly determine annual cell production and wood growth (Lupi et al., 2010; Rossi et al., 2013). Finally, the quality and quantity of available soil nutrients, particularly nitrogen $(\mathrm{N})$, could affect growth independently of their impacts on $\mathrm{C}$ assimilation, because of the relatively constrained stoichiometry of tree biomass (Leuzinger and Hättenschwiler, 2013). These studies suggest that growth is limited by the direct effects of environmental factors (i.e. sink control). However, numerous key environmental factors (e.g. nutrients, temperature and water) affect both sink and source activities, and it is thus difficult to determine whether wood growth is more related to $\mathrm{C}$ supply or to the intrinsic environmental sensitivity of cambium functioning (Fatichi et al., 2014). The extent to which wood growth is under source or sink control is of paramount importance for predicting how trees will respond to global changes and specifically how increasing atmospheric $\mathrm{CO}_{2}$ will affect forest productivity and the future terrestrial $\mathrm{C}$ sink. The implementation of the respective roles of source and sink controls on growth in TBMs is therefore a substantial challenge for modellers, because it may determine our ability to project future forest $\mathrm{C}$ sink, diebacks and distributions (Cheaib et al., 2012; Fatichi et al., 2014; Leuzinger et al., 2013).

The allocation of assimilated $\mathrm{C}$ within forest ecosystems is a complex, integrative process that can be described by several non-exclusive principles (Franklin et al., 2012) that include (i) allometric scaling, (ii) functional balance and (iii) evolution-based optimal responses. (i) The allometric scaling principle is based on the assumption that biophysical laws, such as the mechanical constraints associated with plant hydraulic architecture and the construction of watertransport system (Magnani et al., 2000), determine C partitioning among the different tree compartments. (ii) The functional balance principle suggests that the organ responsible for acquiring the limiting resource is preferentially allocated C. Consistent with this principle, higher $\mathrm{C}$ allocation to fine roots at the expense of $\mathrm{C}$ allocation to wood growth has been reported for poor or dry soils (Chen et al., 2013; Keyes and Grier, 1981). In addition, a possibly greater allocation to root symbionts and exudates at the expense of biomass production has also been reported (Vicca et al., 2012). (iii) Finally, the optimal response principle postulates that allocation maximizes fitness in a fixed environment. This hypothesis agrees with the idea that a dynamic reserve pool acts as temporary storage, possibly at the expense of growth, to promote longterm tree survival (Chapin et al., 1990; Sala et al., 2012). Indeed, time lags between $\mathrm{C}$ uptake and growth have been reported (Gough et al., 2009; Richardson et al., 2013). The optimal response principle is consistent with several wellknown life-history traits, such as preferential allocation to reproduction in ageing plants, which could lead to age-related declines in woody biomass allocation (Genet et al., 2010; Thomas, 2011). The woody biomass increment therefore appears to be under the control of multiple factors. The effects of these drivers are expected to strongly vary in space and time. Consequently, studies have reported conflicting relationships between the $\mathrm{C}$ supply and wood growth (Gielen et al., 2013; Richardson et al., 2013), ranging from no significant relationships (Mund et al., 2010; Rocha et al., 2006) to close relationships on seasonal (Babst et al., 2014; Granier et al., 2008; Zweifel et al., 2010) or annual (Ohtsuka et al., 2009; Peichl et al., 2010; Zweifel et al., 2010) timescales. Determining the key processes that affect wood growth on different spatio-temporal scales is necessary in order to explain these apparently contradictory results using a common framework. Moreover, investigations should be conducted at the species level, because phylogeny may strongly constrain forest functioning (Carnicer et al., 2013; Drobyshev et al., 
Table 1. Climatic features of the studied sites. ETP is annual Penman-Monteith potential evapotranspiration, Precip. is annual precipitation, and Temp. is annual temperature. Values are site averages \pm SD among sites.

\begin{tabular}{lccccccc}
\hline Species & $\begin{array}{c}\text { Number } \\
\text { of plots }\end{array}$ & $\begin{array}{c}\text { Number of } \\
\text { site-years }\end{array}$ & $\begin{array}{c}\text { Elevation } \\
(\mathrm{m})\end{array}$ & $\begin{array}{c}\text { ETP } \\
(\mathrm{mm})\end{array}$ & $\begin{array}{c}\text { Precip. } \\
(\mathrm{mm})\end{array}$ & $\begin{array}{c}\text { Temp. } \\
\left({ }^{\circ} \mathrm{C}\right)\end{array}$ & Source \\
\hline F. sylvatica & 16 & 313 & $565 \pm 326$ & $1010 \pm 121$ & $1001 \pm 133$ & $10.1 \pm 0.98$ & RENECOFOR \\
Q. petraea/Q. robur & 26 & 484 & $193 \pm 76$ & $999 \pm 71$ & $821 \pm 96$ & $10.7 \pm 0.63$ & RENECOFOR \\
P. abies & 6 & 101 & $1056 \pm 313$ & $933 \pm 44$ & $1559 \pm 340$ & $7.1 \pm 1.4$ & RENECOFOR \\
Q. ilex & 1 & 43 & 270 & 1417 & 907 & 13.4 & Puéchabon site \\
\hline
\end{tabular}

2013) and induce different growth determinants among taxa (Genet et al., 2010).

There is a gap between the knowledge obtained from global studies of universal $\mathrm{C}$ allocation rules in forests and our understanding of the cell processes that underlie cambial activity; currently, this gap appears to be the primary obstacle to a more complete understanding of wood growth drivers. In this regard, species-specific studies that evaluate the dynamic of $\mathrm{C}$ partitioning to annual wood growth along soil and climate gradients would be highly useful but are lacking. Unfortunately, there is a scarcity of data sets that combine EC and growth measurements at the same sites (Luyssaert et al., 2007). Here, we circumvented this limitation by complementing stand and soil measurements at a French permanent plot network of 49 forest sites with process-based simulations of annual and seasonal tree $\mathrm{C}$ balance (Fig. 1). Simulations were performed using a process-based model (CASTANEA, Dufrêne et al., 2005) that was thoroughly validated using EC data from throughout Europe (Davi et al., 2005; Delpierre et al., 2009, 2012) and was applied using site-specific parameters. By relating biometric measurements to variables that explain the $\mathrm{C}$ source and sink activity, we evaluated the key drivers of the annual $\mathrm{C}$ allocation to stand wood growth in five species that are representative of the main European forest biomes: Fagus sylvatica, Quercus petraea and Quercus robur for temperate deciduous broadleaf forests; Picea abies, for high-latitude and high-altitude evergreen needleleaf forests; and Quercus ilex, an evergreen broadleaf species from Mediterranean forests. Specifically, the relative influence of annual and seasonal (from 1 month to 1 year) tree $\mathrm{C}$ balance (source control), direct environmental control (water and temperature effects on sink activity) and allocation adjustments related to age, past climate conditions, competition intensity and soil nutrient availability on tree growth were considered (Fig. 1). We aimed to (1) quantify the relative contributions of source and sink controls to the spatio-temporal dynamic of forest wood growth across a wide range of environmental contexts and (2) provide information that can be used to refine the representation of forest growth causalities in TBMs.

\section{Materials and methods}

We based our analyses on three complementary data sources: field measurements, climatic variables from atmospheric reanalysis (Vidal et al., 2010) and process-based simulation data. This hybrid approach allowed us to assess and disentangle the effects of previously reported environmental and endogenous drivers of $\mathrm{C}$ allocation to wood growth (Fig. 1).

\subsection{Study sites and field data}

We gathered field measurements from 48 plots from the French Permanent Plot Network for the Monitoring of Forest Ecosystems (RENECOFOR; Ulrich, 1997) and the Puéchabon tower flux site (Martin-StPaul et al., 2013). The location and general climatic features of these plots are shown in Fig. 2 and Table 1. Complete site description is available in Supplement S1.

\subsubsection{Growth measurements and historical stand growth reconstruction}

Growth measurements were obtained via two methods. The first method was dendrochronological sampling, in which 12 to 30 overstorey trees per plot were cored to the pith at breast height with an incremental borer. Cores were collected in 1994 at the RENECOFOR sites and in 2008 at the Puéchabon site (Lebourgeois, 1997; J. M. Ourcival, unpublished data). Tree circumferences at breast height (CBHs) and total heights were also measured. The average stand age was inferred from the tree ring series. The second method was forest inventories, in which extensive CBH surveys were conducted in a 0.5 ha area of every plot (Cluzeau et al., 1998; Gaucherel et al., 2008; J. M. Ourcival, unpublished data).

Tree ring series were combined with the $\mathrm{CBH}$ surveys to reconstruct the historical CBHs of every tree on the plots (over 8 to 43 years, Supplement S1). The entire stand tree $\mathrm{CBH}$ distribution was reconstructed from the CBHs of the sampled trees using an empirical tree competition model (Deleuze et al., 2004). This model stipulates that only trees with a $\mathrm{CBH}$ above a given threshold ( $\sigma$, the minimum circumference needed to gain direct access to sunlight) have a significant level of growth. Overstorey trees then have an annual basal area growth rate that is proportional to their size, 


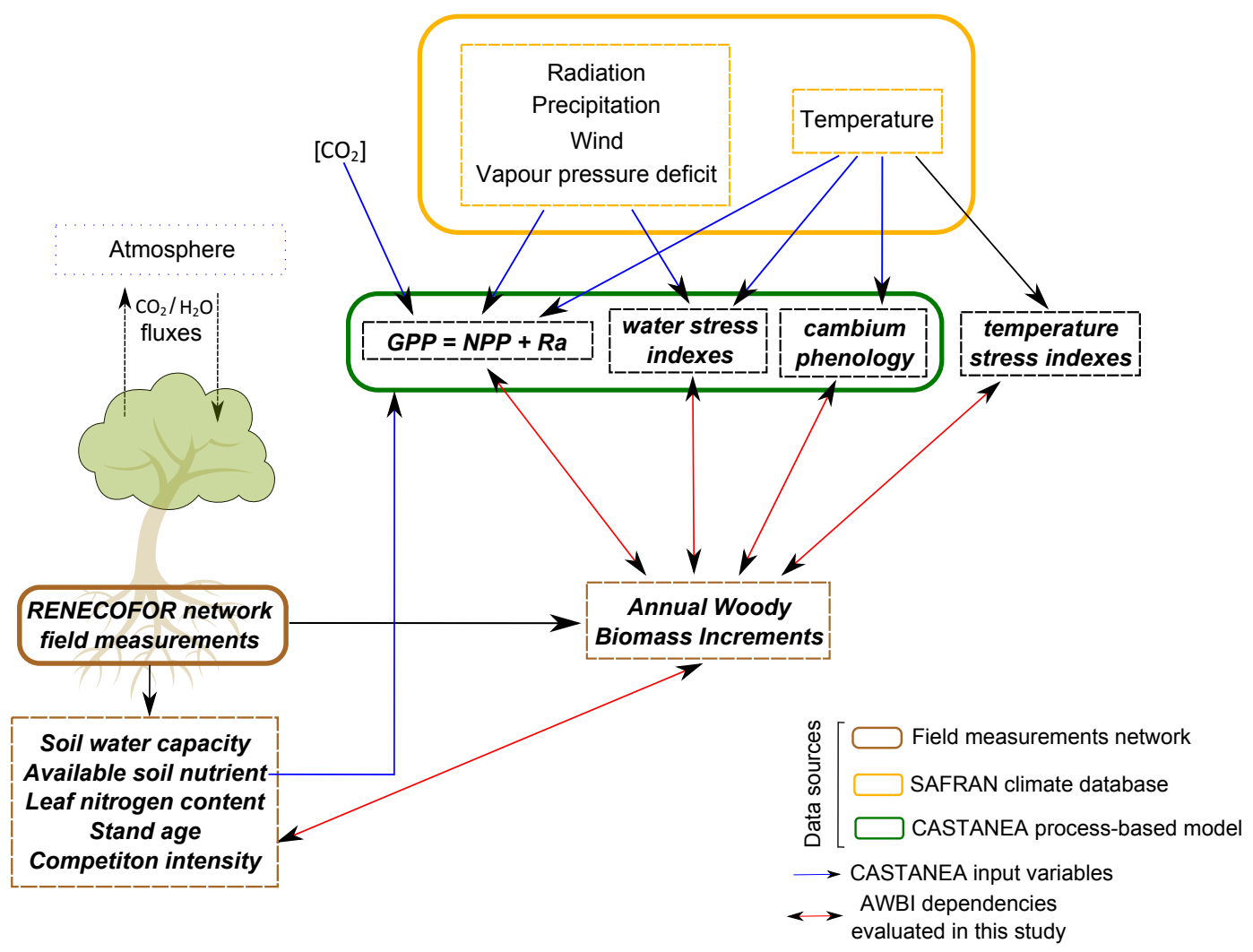

Figure 1. The conceptual framework and the three sources of data (field measurements, climate reanalysis and process-based simulations) used in the analyses.

according to a slope coefficient, $\gamma$. Following the work of Guillemot et al. (2014), the model was calibrated annually, beginning at year $(n)$ of the core sampling and used iteratively to reconstruct the past stand $\mathrm{CBH}$ growth. The $\sigma$ parameter was first defined using an empirical relationship with the maximum $\mathrm{CBH}$ of the stand tree distribution from year $(n)$. The $\gamma$ parameter was then adjusted using the tree rings measured on the sampled trees in year $(n-1)$. The parameterized model was finally used to predict the basal area increments of all the trees in the distribution, and consequently the tree $\mathrm{CBH}$ distribution in the year $(n-1)$. A detailed description of the iterative process can be found in Supplement S2 and in Guillemot et al. (2014).

The inferred past trajectory of the stand $\mathrm{CBH}$ distribution was used to calculate the historical number of stems (numstem, Table 2) and stand basal area, which we considered to be a proxy for within-stand competition intensity (SBA, Table 2; Kunstler et al., 2011). The historical total woody stand biomass was also calculated (Supplement S3) using species-specific tree-level allometric functions (Bontemps et al., 2009, 2012; Dhôte and Hercé, 1994; Seynave et al., 2005; Vallet et al., 2006) and wood density models (Bouriaud et al., 2004; Wilhelmsson et al., 2002; Zhang et al., 1993). For $Q$. ilex, we used the appropriate function from Rambal et al. (2004) to calculate the stand woody biomass from CBHs.
Past annual woody biomass increments (AWBIs) were then inferred (Supplement S4).

\subsubsection{Measurements of stand characteristics}

The stand measurements included the soil water holding capacity (SWHC), leaf area index (LAI), leaf N content (LNC) and soil nutrient availability (SNA). The SWHC was estimated via the soil depth and texture measured at two soil pits per plot (Brêthes and Ulrich, 1997). The LAI was estimated from litter collection (Pasquet, 2002), and the sunlit LNC was determined annually for eight trees between 1993 and 1997 (Croisé et al., 1999).

SNA was assessed as the soil's $\mathrm{C}: \mathrm{N}$ biomass ratio, the absolute value of the cation-exchange capacity and the per cent base saturation (Ponette, 1997). These soil indices were measured at three depths ( 0 to $10 \mathrm{~cm}, 10$ to $20 \mathrm{~cm}, 20$ to $40 \mathrm{~cm}$ ) and were used to categorize the soil plots into three nutrient classes, from low to high nutrient availability (Supplement S5). The SNA, SWHC and LNC were used to characterize plot fertility in the statistical analyses (Table 2). 
Table 2. Description of the explanatory variables considered in the analyses. The type category indicates the source of the data: measurement (M), SAFRAN climate database (C) or CASTANEA simulations (S). Scale categories indicate the variables considered in spatial (S) and/or temporal (T) analyses.

\begin{tabular}{|c|c|c|c|c|}
\hline IDs & Description & Unit & Type & Scale \\
\hline age & Stand age & years & M & $\mathrm{S}$ \\
\hline AWBI & Annual woody biomass increment & $\mathrm{gCm}^{-2}$ & M & ST \\
\hline SBA & Stand basal area & $\mathrm{m}^{2}$ & M & S \\
\hline camb_onset & Onset of the cambial activity & day of the year & $\mathrm{S}$ & $\mathrm{T}$ \\
\hline $\mathrm{GPP}_{\mathrm{gp}}$ & Gross primary production of the current $(y)$ growth period & $\mathrm{gCm}^{-2}$ & S & ST \\
\hline $\operatorname{GPP}_{y-1}$ & Gross primary production of the previous $(y-1)$ year & $\mathrm{gCm}^{-2}$ & S & $\mathrm{T}$ \\
\hline frost & $\begin{array}{l}\text { Sum of the average daily temperatures below }-2{ }^{\circ} \mathrm{C} \text { during the last winter (year } \\
y-1 \text { and y) }\end{array}$ & ${ }^{\circ} \mathrm{C}$ & $\mathrm{C}$ & ST \\
\hline LNC & Leaf nitrogen content & $\mathrm{g} \mathrm{NgDM}^{-1}$ & M & S \\
\hline $\mathrm{NPP}_{\mathrm{gp}}$ & Net primary production of the current $(y)$ growth period & $\mathrm{gCm}^{-2}$ & S & ST \\
\hline $\mathrm{NPP}_{y-1}$ & Net primary production of the previous $(y-1)$ year & $\mathrm{gCm}^{-2}$ & $\mathrm{~S}$ & $\mathrm{~T}$ \\
\hline numstem & Stem density & number ha $^{-1}$ & M & $S$ \\
\hline SNA & Class of soil nutrient availability (1: low; 2 : medium; 3 : high) & unitless & M & S \\
\hline SWC & Soil water holding capacity & $\mathrm{mm}$ & M & $\mathrm{S}$ \\
\hline templim & $\begin{array}{l}\text { Number of days of the current }(y) \text { growth period with an average temperature below } \\
6^{\circ} \mathrm{C}\end{array}$ & number of days & $\mathrm{C}$ & ST \\
\hline $\mathrm{Ragp}_{\mathrm{gp}}$ & Autotrophic respiration of the current $(y)$ growth period & $\mathrm{gCm}^{-2}$ & S & ST \\
\hline $\mathrm{Ra}_{y-1}$ & Autotrophic respiration of the previous $(y-1)$ year & $\mathrm{gCm}^{-2}$ & S & $\mathrm{T}$ \\
\hline WS_pergp & $\begin{array}{l}\text { Number of days of the current }(y) \text { growth period with a soil water content below } \\
60 \% \text { of the soil water holding capacity }\end{array}$ & number of days & S & ST \\
\hline WS_per $y-1$ & $\begin{array}{l}\text { Number of days of the previous }(y-1) \text { year with a soil water content below } 60 \% \\
\text { of the soil water holding capacity }\end{array}$ & number of days & $\mathrm{S}$ & $\mathrm{T}$ \\
\hline WS_int ${ }_{g p}$ & Water stress intensity index over the current $(y)$ growth period & unitless & $\mathrm{S}$ & ST \\
\hline WS_int $y-1$ & Water stress intensity index of the previous $(y-1)$ year & unitless & $S$ & $\mathrm{~T}$ \\
\hline
\end{tabular}

\subsection{Climate data}

The following meteorological variables at the hourly temporal scale (with $8 \mathrm{~km}$ spatial resolution) were obtained from the SAFRAN atmospheric reanalysis (Vidal et al., 2010): global radiation, rainfall, wind speed, air humidity and air temperature. Temperature, which was related to the average altitudes of the SAFRAN cells, was corrected using plotspecific elevation measurements (assuming a lapse rate of $0.6^{\circ} \mathrm{K}$ per $100 \mathrm{~m}$, Supplement $\mathrm{S} 1$ ). These variables were used for climate forcing in the CASTANEA model (Dufrêne et al., 2005; see the following section). In addition, two annual temperature indices were used as proxies of winter frost damage and low temperature stress during the growing period (frost and templim ${ }_{\mathrm{gp}}$, respectively, Table 2).

\subsection{Process-based simulation data}

We used the CASTANEA model to simulate an ensemble of diagnostic variables that are related to the $\mathrm{C}$ source and sink activity of forest stands: the elementary components of the tree $\mathrm{C}$ balance, bioclimatic water stress indices and the onset of the biomass growth. The eco-physiological process-based CASTANEA model aims to simulate $\mathrm{C}$ and water fluxes and stocks of a monospecific, same-aged forest stand on a rota- tion timescale. The hourly stand-atmosphere $\mathrm{C}$ fluxes predicted by the CASTANEA model have been thoroughly validated using EC data from throughout Europe (Davi et al., 2005; Delpierre et al., 2009, 2012). Importantly, the biophysical hypotheses that were formalized in this model are able to reproduce the interplay of the complex mechanisms that leads to inter-annual variability in the stand $\mathrm{C}$ balance (Delpierre et al., 2012); modelling this interplay has been recognized as a substantial challenge for TBMs (Keenan et al., 2012). A complete description of CASTANEA is provided in Dufrêne et al. (2005), and subsequent modifications are described in Davi et al. (2009) and Delpierre et al. (2012). For the purpose of the present study, CASTANEA was parameterized with site-specific SWHC and LNC values. The measured LAI and total woody biomass were used to initialize the model simulations. The model's ability to reproduce the annual variability in LAI and the forest growth has been recently validated (Guillemot et al., 2014). Nevertheless, the annual standing woody biomass was forced to conform to the observed values, because the model was used for diagnostic purposes in this study.

Several groups of variables were simulated and aggregated on an annual basis (Table 2): 


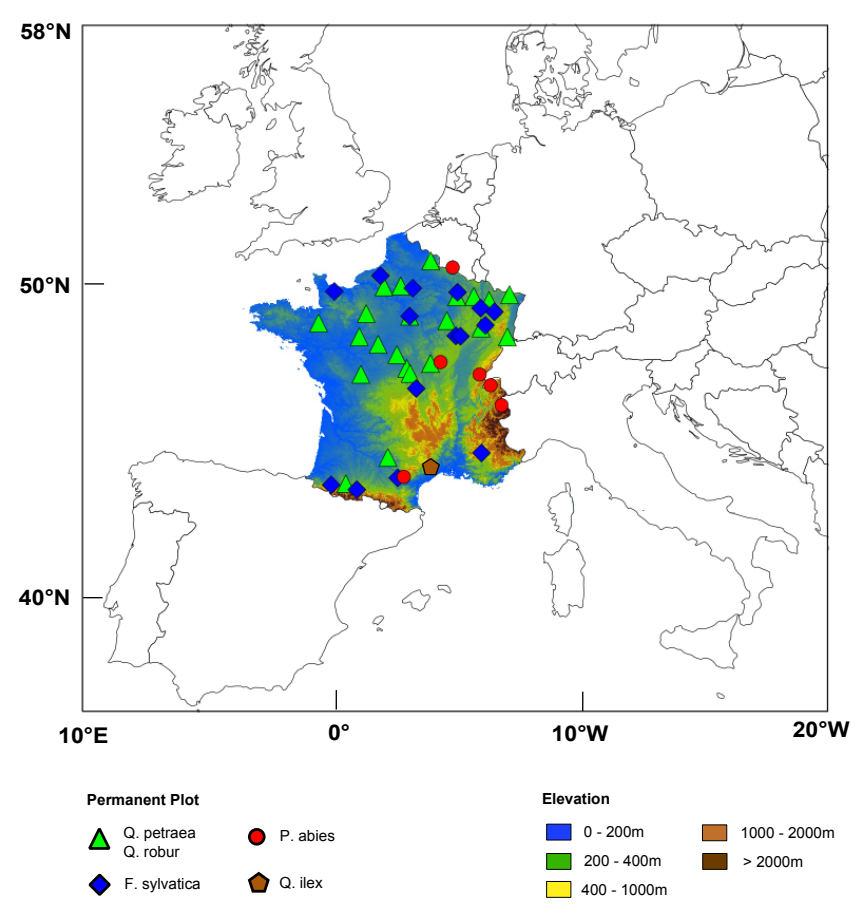

Figure 2. Locations of the study sites.

1. The elementary components of the tree $C$ balance. These components included the GPP, autotrophic respiration $(\mathrm{Ra})$ and net balance (i.e. net primary productivity, NPP = GPP $-\mathrm{Ra}$ ). For a given year $\mathrm{y}$, we aggregated the hourly simulated $\mathrm{C}$ fluxes over different seasonal time periods, with starting days that ranged from 30 to 190 and ending days that ranged from 190 to 350, at a 2-day resolution. The $\mathrm{C}$ fluxes were also summed (i) for the species-specific biomass growth periods reported in the literature $\left(\mathrm{GPP}_{\mathrm{gp}}, \mathrm{Ra}_{\mathrm{gp}}\right.$ and $\mathrm{NPP}_{\mathrm{gp}}$; Supplement S6) and (ii) for the entire preceding year $(y-1)$ as a proxy of the forest $\mathrm{C}$ status induced by past climate conditions (lagged effect, $\mathrm{GPP}_{y-1}, \mathrm{Ra}_{y-1}$ and $\mathrm{NPP}_{y-1}$ ).

2. Bioclimatic water stress indices. These indices included the intensity and duration of water stress (WS_int and WS_per ${ }_{g p}$, respectively; Supplement S7) during species-specific growing periods that have been reported in the literature (Supplement S6). The CASTANEA model simulated the daily soil water balance, based on a bucket soil sub-model with two layers (a top soil layer and a total soil layer that includes the top soil

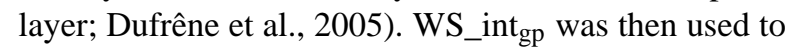
quantify the intensity of water stress by summing the reduc index on a daily basis (Granier et al., 1999).

$\operatorname{reduc}_{t}=\max \left(0, \min \left(1, \frac{\mathrm{SWC}_{t}-\mathrm{SWC}_{\mathrm{wilt}}}{0.4 \times\left(\mathrm{SWC}_{\mathrm{fc}}-\mathrm{SWC}_{\mathrm{wilt}}\right)}\right)\right)$,

where $\mathrm{SWC}_{t}$ is the soil water content on day $t(\mathrm{~mm})$, $\mathrm{SWC}_{\text {wilt }}$ is the soil water content at the wilting point $(\mathrm{mm})$ and $\mathrm{SWC}_{\mathrm{fc}}$ is the soil water content at field capacity $(\mathrm{mm})$.

WS_pergp is the number of days of the current growth period during which the soil water content was less than $60 \%$ of the soil water holding capacity (Table 2, modified from Mund et al., 2010). Water stress indices were also calculated for the entire preceding year (lagged effect of water stress, WS_int $y_{y-1}$ and WS_per ${ }_{y-1}$ ).

3. The onset of the biomass growth (camb_onset). We used a new growth-onset module (David, 2011; N. Delpierre and N. K. Martin-StPaul, unpublished results) based on a temperature sum trigger (Supplement S8).

\subsection{Statistical analyses}

\subsubsection{General overview}

Statistical analyses were conducted in three complementary steps for each studied species. (1) We calculated the correlation of the AWBIs and the C fluxes (GPP, NPP and Ra) aggregated seasonally (from 1 month to 1 year) to evaluate the relationship between the $\mathrm{C}$ supply and annual biomass growth changes. (2) The dependences of the AWBIs on the C source and the sink activity were evaluated on an inter-site spatial scale to determine the influence of the site characteristics on biomass growth. The relationship between the age and $\mathrm{C}$ allocation to woody biomass was also evaluated in this step. By using the age differences among sites, our chronosequence included a large range of ages (including stands that ranged in age from approximately 30 to 150 years old, Table S1 in Supplement). (3) Finally, the drivers of AWBI were assessed temporally to determine the factors that were responsible for variability in the inter-annual biomass growth.

Because many environmental factors affect both forest sink and source activities, there may be strong covariance among the tree $\mathrm{C}$ balance and proxies of environmental stress (Fatichi et al., 2014) that could hamper the inferential power of classical statistical tests (Graham, 2003). However, the explanatory variables used in this study generally had correlation coefficients of less than 0.7 , the level above which collinearity begins to severely affect model performance (Dormann et al., 2013). One exception was the correlation of components of the tree $\mathrm{C}$ balance (because $\mathrm{NPP}=\mathrm{GPP}-\mathrm{Ra}$ ). Consequently, the tree $\mathrm{C}$ balance components were introduced one at a time into the models. In addition, temporal growth dependencies were evaluated using the random forest (RF) learning method (Breiman, 2001). A number of studies have empirically demonstrated the effectiveness of RF at identifying the "true" predictors among a large number of correlated candidate predictors (e.g. Archer and Kimes, 2008; Cutler et al., 2007; Genuer et al., 2010). The explanatory variables considered in our spatial and temporal analyses are presented in Table 2 and Fig. 1. Analyses were conducted with $\mathrm{R}$ software ( $\mathrm{R}$ Development Core 
Table 3. Relationships of annual wood growth and the components of the seasonal forest carbon balance: NPP, GPP and Ra. The start and end terms (day of the year) indicate the carbon flux period that yielded the maximum value for the median of the growth-flux correlations among sites. The $r$ term is the maximum obtained for the median of the site-specific Pearson correlation coefficients; values that are significantly different from 0 are indicated (* indicates $P<0.05$ and ${ }^{* *}$ indicates $P<0.001$ ). The $\sigma$ term is the standard deviation of the Pearson correlation values among sites.

\begin{tabular}{|c|c|c|c|c|c|c|c|c|c|c|c|c|}
\hline \multirow[t]{2}{*}{ Species } & \multicolumn{4}{|c|}{ GPP } & \multicolumn{4}{|c|}{$\mathrm{Ra}$} & \multicolumn{4}{|c|}{ NPP } \\
\hline & start & end & $r$ & $\sigma$ & start & end & $r$ & $\sigma$ & start & end & $r$ & $\sigma$ \\
\hline F. sylvatica & 124 & 258 & $0.62^{* *}$ & 0.18 & 96 & 200 & $-0.29 *$ & 0.33 & 126 & 262 & $0.58^{* *}$ & 0.24 \\
\hline Q. petraea/Q. robur & 136 & 214 & $0.59^{* *}$ & 0.25 & 98 & 192 & $0.31^{*}$ & 0.24 & 130 & 214 & $0.50^{* *}$ & 0.28 \\
\hline P. abies & 32 & 262 & $0.52^{* *}$ & 0.38 & 78 & 348 & 0.11 & 0.52 & 32 & 200 & $0.49^{* *}$ & 0.29 \\
\hline Q. ilex & 186 & 226 & 0.60 & & 36 & 256 & -0.26 & & 186 & 226 & 0.58 & \\
\hline
\end{tabular}

Team 2013) using the packages lme4 (Bates et al., 2007), randomForest (Liaw and Wiener, 2002) and MuMIn (Barton and Barton, 2014). Because Quercus petraea and Quercus robur are difficult to distinguish in the field and have a high hybridization rate (Abadie et al., 2012), these two species were grouped in the analyses and are hereafter collectively referred to as "temperate oaks".

\subsubsection{Correlations between growth and $\mathrm{C}$ fluxes}

Pearson correlations between the AWBIs and simulated C fluxes in different seasonal time periods were calculated separately for each site. The highest median correlation value for each species was retained and tested against zero using Wilcoxon signed-rank tests. Critical correlations (i.e. the threshold values for a significant difference with the retained maximum correlation) were determined to evaluate the sensitivity of the correlation values to changes in the $\mathrm{C}$ flux aggregation periods.

\subsubsection{Drivers of spatial variations in biomass growth}

The drivers of spatial variations in biomass growth were evaluated using multiple-regression models using an information-theoretic approach (Burnham and Anderson, 2002). The AWBIs and the considered explanatory variables were averaged for each plot. The variables introduced into the linear models were centred and scaled such that their normalized coefficient estimates indicated the relative influence of the predictors on the AWBI. The elementary components of tree $\mathrm{C}$ balance (NPP, GPP and Ra) were introduced one at a time into the models. For each species, multiple-regression models that contained all possible combinations of the explanatory variables were fitted. The models were compared using the second-order Akaike information criterion (AIC), and all models with an Akaike weight of at least $1 \%$ of the best approximating (lowest AIC) model were considered to be plausible (Burnham and Anderson, 2002). Ultimately, we retained the variables that appeared in at least $95 \%$ of the selected models. Models fitted using P. abies data were restricted to a maximum of three explanatory variables because of the small sample size $(n=6$, Table 1$) . Q$. ilex $(n=1)$ was not considered in the spatial analyses. The uncertainty of the simulated $\mathrm{C}$ fluxes was assessed in the analyses using a bootstrap procedure (Chernick, 2011): all linear models were fitted 1000 times, and at each iteration, the $\mathrm{C}$ flux values were randomly sampled within the root-mean-square error of the CASTANEA simulations (Supplement S9) to obtain a parameter estimate distribution for each variable. We finally retained the explanatory variables with parameter estimate distributions that excluded the zero value at a two-tailed probability level of $5 \%$.

\subsubsection{Drivers of temporal variations in biomass growth}

A temporal analysis was conducted on the standardized AWBI series: a double-detrending process was applied to each series based on an initial linear regression model, followed by fitting a cubic smoothing spline with a $50 \%$ frequency response cut-off (Mérian et al., 2011). For analysing the temporal variations in biomass growth we used an RF learning method (Breiman, 2001), which was possible because of the large sample size ( $n=931$ site-years). The RF learning method is a non-parametric method that is used to rank the contribution of different explanatory variables and evaluate their marginal effects on a variable of interest without assuming an a priori dependence. The RF method combined 500 binary decision trees that were built using bootstrap samples from the initial data set. The decision trees aimed to reduce the heterogeneity of the explained variable in the resulting branches. For each of the 500 trees, the data that were not involved in the tree construction were used for validation. The tree predictions and errors were then averaged to provide the final RF results. The RF method does not overfit or require cross-validation (Cutler et al., 2007). A subset of explanatory variables was randomly chosen at each node, thus reducing the effect of collinear variables on the output. The RF method was used to select variables that explained the temporal variability in biomass growth (Genuer et al., 2010). Variable selection relied on permutation importance, i.e. the existence of an increase in the global mean 
Table 4. Spatial dependences of the annual woody growth: multiple-regression estimates. Data have been centred and scaled. GPP ${ }_{\mathrm{gp}}$ is the gross primary production of the growth period, age is the average age of the stand, and SBA is the stand basal area (Table 2). Values: estimates $[F$ values]. All estimate values differed significantly from $0(P<0.001)$. All variables were retained in the bootstrap procedure $($ see main text).

\begin{tabular}{|c|c|c|c|c|c|}
\hline \multirow[t]{2}{*}{ Species } & \multicolumn{5}{|c|}{ Estimates } \\
\hline & $\mathrm{GPP}_{\mathrm{gp}}$ & age & SBA & $P$ & adj. $R^{2}$ \\
\hline Q. petraea/Q. robur & & $-8.88 \times 10^{-1}[39.5]$ & $4.27 \times 10^{-1}[19.5]$ & $<10^{-4}$ & 0.69 \\
\hline F. sylvatica & $5.07 \times 10^{-1}[59.4]$ & $-6.96 \times 10^{-1}[61.6]$ & & $<10^{-4}$ & 0.88 \\
\hline P. abies & $8.25 \times 10^{-1}[8.6]$ & & & 0.04 & 0.60 \\
\hline
\end{tabular}

square error when a given variable was randomized in the validation subsamples. The forms of the dependences were illustrated by partial dependence plots (graphical depiction of the marginal effect of a given variable; Cutler et al., 2007). We used this information (variable selection and dependence forms) to test for the significance of the temporal AWBI dependences within the linear model. The uncertainty in the simulated C fluxes was considered in the linear models, following the procedure described in the spatial analysis section.

\section{Results}

\subsection{Relationship between woody biomass growth and C fluxes}

The elementary components of the simulated seasonal tree $\mathrm{C}$ balance differed in terms of their relationships with the inter-annual variability of the annual woody biomass increments (AWBI, Table 3). The simulated seasonal GPP and NPP were linked to AWBIs with a comparable agreement between species. However, the simulated Ra had weak and often non-significant relationships with the AWBIs across the 49 studied plots. The strongest correlations were obtained for flux aggregation periods that (i) were generally consistent within a species for GPP and NPP but different for Ra and (ii) strongly differed among species (Table 3 ). The coefficients of variation of the simulated annual NPP, GPP and Ra across the 49 studied sites were $10.8 \pm 3,7.4 \pm 2$ and $6.8 \pm 3 \%$, respectively. GPP and NPP were summed from the beginning of May to the beginning of August and September, in temperate oaks and F. sylvatica, respectively. The longest GPP and NPP aggregation periods were obtained for P. abies (from the beginning of February to mid-September), and the shortest period were found for $Q$. ilex (from the beginning of July to mid-August). Minor (less than 20 days) changes in the flux aggregation period associated with the maximum simulated flux-AWBI correlation usually marginally affected the correlation values (Supplement S10). Consequently, aggregation periods that were less than 13 days different (either in terms of their starting or ending dates) from the values reported in Table 3 were generally not significantly lower than the maximum values (see the critical values presented in Supplement S10).

\subsection{Spatial dynamic of $\mathrm{C}$ allocation to woody biomass growth}

The inter-site variability in biomass growth was well explained by the selected multiple-regression models $\left(R^{2} \geqslant 0.6\right)$. We highlighted that species varied in terms of their inter-site dependences (Table 4). The simulated C supply during the growth period $\left(\mathrm{GPP}_{\mathrm{gp}}\right.$, Table 2$)$ was positively correlated with biomass growth in F. sylvatica and P. abies, whereas there was no significant relationship between the average AWBI and photosynthesis among sites for temperate oaks (Fig. 3a). Notably, the final models did not include $\mathrm{NPP}_{\mathrm{gp}}$ or Ragp for any species. The stand age was an important driver of biomass growth in temperate oaks and $F$. sylvatica. The stand age explained a substantial portion of the AWBI: $C$ supply ratio in all species, although the relationship was not significant for P. abies (Fig. 3b). The fraction of $\mathrm{C}$ sequestered in woody biomass decreased with stand age (Table 4, Fig. 3b) and was reduced by half in temperate oaks and $F$. sylvatica stands that were between 50 and 150 years of age (from 0.3 to 0.13 and from 0.25 to 0.1 , respectively). Additionally, we identified a significant and positive effect of stand basal area on both AWBI (Table 4) and the AWBI : GPP gp ratio (data not shown) in temperate oaks.

\subsection{Temporal dynamic of carbon allocation to woody biomass growth}

The ranking of the drivers of biomass growth obtained using the RF algorithm indicated that the temporal AWBI dependences varied among species (Fig. 4). The growth of temperate deciduous species was under a more complex environmental control than the growth of $P$. abies and $Q$. ilex, with several variables explaining a substantial portion of the annual variability in AWBI (Fig. 4a, b). Simulated C supply $\left(\mathrm{GPP}_{\mathrm{gp}}\right)$ was strongly related to the AWBI of temperate oaks and F. sylvatica and, to a lesser extent, P. abies (Fig. 4a, b, c), with positive marginal effects (Fig. 5a, e, h). The duration of water stress during the growth period (WS_pergp) 

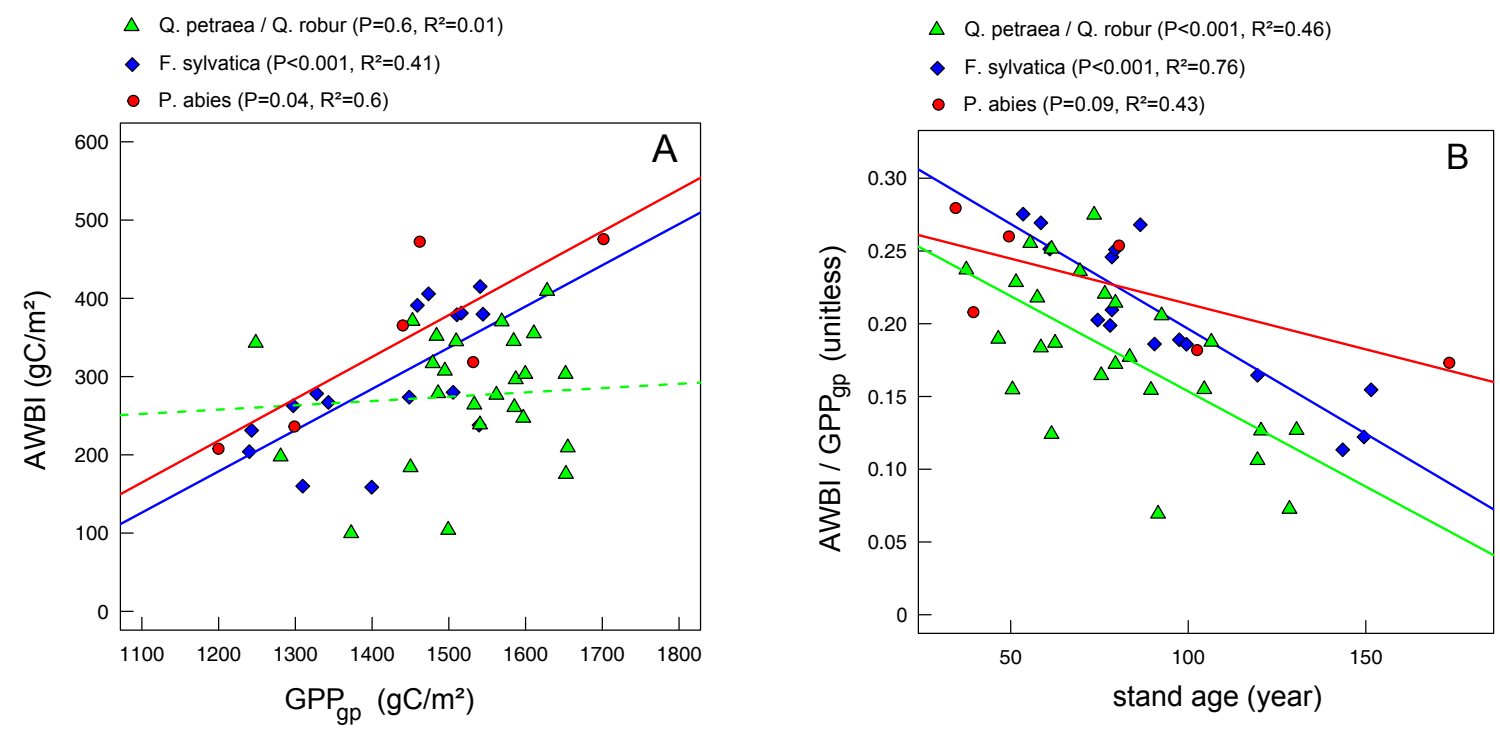

Figure 3. Spatial dependences of annual wood growth. (a) Relationship of the AWBI and the GPP of the growth period (GPP $\mathrm{gp}_{\text {) averaged }}$ over sites. (b) Age-related decline of the C partitioning to AWBI (AWBI / GPP $\mathrm{gp}_{\text {). }}$.

Table 5. Temporal dependences of the annual woody growth: multiple-regression estimates. Data have been centred and scaled. GPP $\mathrm{gp}_{\mathrm{g}}$ the gross primary production of the growth period, WS_pergp is a water stress index of the growth period, WS_int ${ }_{y-1}$ is a water stress index of the previous year, templim is a low temperature index of the growth period (Table 2$). D 1$ and $D 2$ are dummy variables $(D 1=0$ if $\mathrm{GPP}_{\mathrm{gp}}<1400 \mathrm{~g} \mathrm{Cm}^{-2}, D 1=1$ otherwise; $D 2=0$ if $\mathrm{GPP}_{y-1}<1550 \mathrm{~g} \mathrm{Cm}^{-2}, D 2=1$ otherwise; see Fig. 5). $\rho$ is the parameter of the first-order autoregressive process used to model the temporal autocorrelation of within-stand errors. Values: estimates [ $F$ values]. Estimate values differing from 0 are indicated $\left({ }^{*} P<0.05,{ }^{* *} P<0.01,{ }^{* * *} P<0.001\right)$. The estimate with a $\Delta$ index indicates variable not retained in the bootstrap procedure (see main text).

\begin{tabular}{|c|c|c|c|c|}
\hline \multirow[t]{2}{*}{ Estimates } & \multicolumn{4}{|c|}{ Species } \\
\hline & $\begin{array}{c}Q . \text { petraeal } \\
Q . \text { robur }\end{array}$ & F. sylvatica & P. abies & Q. ilex \\
\hline $\mathrm{GPP}_{\mathrm{gp}}$ & $3.26 \times 10^{-1 * * *}$ & $4.87 \times 10^{-1 * * *}$ & $2.4 \times 10^{-1 *}[3.5]$ & \\
\hline WS_pergp & $-1.09 \times 10^{-1 * *}$ & $-2.04 \times 10^{-1 * * *}$ & & $-5.8 \times 10^{-1 * * *}$ \\
\hline WS_int $_{y-1}$ & & $-2.37 \times 10^{-1 * * *}$ & & $-2.2 \times 10^{-1 *}[6.3]$ \\
\hline $\operatorname{GPP}_{y-1}$ & $3.82 \times 10^{-1 *}[3.3]$ & & $-4 \times 10^{-1 * *}[3.2]$ & \\
\hline templim & $-9.60 \times 10^{-2 * * \Delta}$ & & $-1.26^{* * *}[3.5]$ & \\
\hline$D 1$ & & & $-2.4 \times 10^{-1 * * *}$ & \\
\hline$D 2$ & $-3.9 \times 10^{-1 * *}[0.8]$ & & & \\
\hline$D 1 \cdot \mathrm{GPP}_{\mathrm{gp}}$ & & & $1.33^{* *}[8.2]$ & \\
\hline$D 2 \cdot \mathrm{GPP}_{y-1}$ & $-4 \times 10^{-1 * *}[6.4]$ & & & \\
\hline$\rho$ & 0.61 & 0.68 & 0.52 & 0.44 \\
\hline$P$ & $<10^{-4}$ & $<10^{-4}$ & $7.7 \times 10^{-3}$ & $<10^{-4}$ \\
\hline adj. $R^{2}$ & 0.21 & 0.42 & 0.20 & 0.43 \\
\hline
\end{tabular}

was the predominant driver of the AWBI variability of $Q$. ilex, and was also strongly related to growth in temperate deciduous species. Low temperatures during the growth period (templim ${ }_{\mathrm{gp}}$ ) most substantially affected $P$. abies and also explained a portion of the variability in AWBI of temperate oaks. The simulated water and temperature stress indices had negative and quasi-linear marginal effects on the AWBI
(Fig. 5). Finally, environmental lagged effects contributed substantially to the AWBI variability in all species: the water stress intensity of the previous year (WS_int $\left.{ }_{y-1}\right)$ affected the growth of $F$. sylvatica and $Q$. ilex, whereas the simulated $\mathrm{C}$ supply of the previous year $\left(\mathrm{GPP}_{y-1}\right)$ affected temperate oaks and $P$. abies. Lagged effects generally revealed a threshold in marginal dependences, with a significant negative ef- 

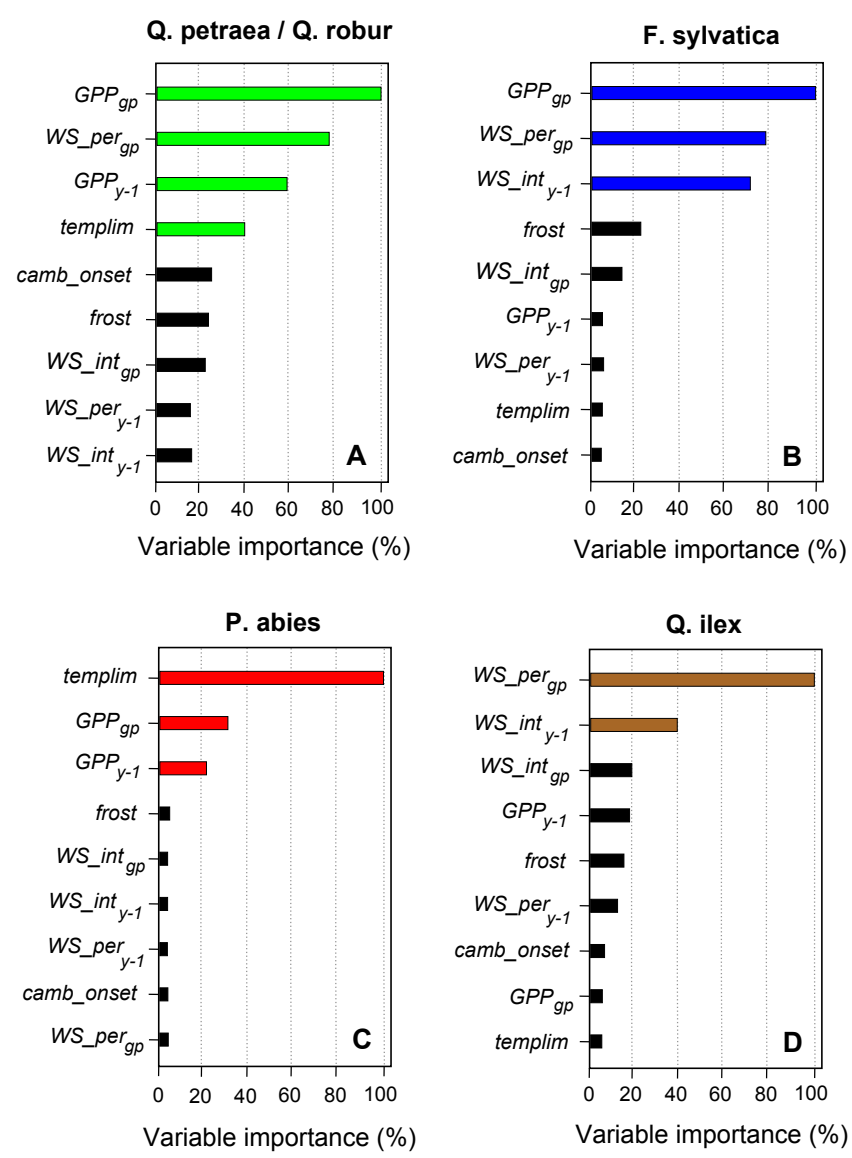

Figure 4. Temporal dependences of annual wood growth: the roles of explanatory variables from RF classification. Variable importance is expressed as the percentage of the importance of the topranked explanatory variable. The variable identifiers (IDs) are listed in Table 2. The coloured variables were retained in subsequent analyses.

fect on AWBI only under high water stress or low C supply (Fig. 5). The effects of the retained variables (Fig. 4) were evaluated via multiple-regression models that used dummy variables to test for the significance of slope changes when thresholds appeared on partial plots (Fig. 5). The models explained approximately $20 \%$ of the variability in the AWBI for temperate oaks and P. abies, and approximately $40 \%$ of the variability for $F$. sylvatica and $Q$. ilex (Table 5). All of the explanatory variables had significant effects, but templim was not retained in the models for temperate oaks after the bootstrap procedure that accounted for the uncertainty of the C flux simulations. We observed significant changes in the slopes of the effect of GPP $y-1$ on temperate oaks and the effect of $\mathrm{GPP}_{\mathrm{gp}}$ on $P$. abies (Table 5). The models with $\mathrm{NPP}_{\mathrm{gp}}$ and $\mathrm{NPP}_{y-1}$ variables revealed the same AWBI dependences as the models described above, but with reduced explanatory power. The models with $\mathrm{Ra}_{\mathrm{gp}}$ and $\mathrm{Ra}_{y-1}$ variables were not significant (data not shown).

\section{Discussion}

This study quantified the $\mathrm{C}$ that is allocated annually to the woody biomass increment for five species that are representative of the main European forest biomes. By complementing field measurements from a permanent plot network with process-based modelling, our approach circumvented the limitation of EC data scarcity and characterized the annual partitioning of $\mathrm{C}$ into woody biomass at 49 sites over France (931 site-years). We were thus able to identify the species-specific drivers of the spatio-temporal dynamics of the allocation of $\mathrm{C}$ to wood growth along ecological gradients.

\subsection{The correlation between the tree $\mathrm{C}$ balance and woody biomass growth}

Relating EC-based estimates of forest $\mathrm{C}$ balance and biometric measurements of woody biomass growth has been the focus of an increasing number of studies. These studies can enhance our understanding of ecosystem $\mathrm{C}$ dynamics but have so far provided conflicting conclusions. Indeed, the correlation between woody biomass growth and forest $\mathrm{C}$ gain has been reported as both non-significant (Mund et al., 2010; Richardson et al., 2013; Rocha et al., 2006) and highly significant (Babst et al., 2014; Ohtsuka et al., 2009; Peichl et al., 2010; Zweifel et al., 2010). Accordingly, the relationships between AWBI and $\mathrm{C}$ fluxes reported in this study strongly varied among sites for each of the species studied (Table 3). Nevertheless, the annual woody biomass increment was consistently related to $\mathrm{GPP}_{\mathrm{gp}}$ and $\mathrm{NPP}_{\mathrm{gp}}$, and only marginally to $R a_{\mathrm{gp}}$ for the majority of sites (Table 3 ). Babst et al. (2014) reported a similar dependence of biomass growth on $\mathrm{C}$ fluxes at five sites that spanned a wide range of latitude in Europe. The authors attributed this result to a common sensitivity of $\mathrm{C}$ assimilation and biomass growth to the water balance. Our results also support the view that biomass growth and tree $\mathrm{C}$ balance are under the control of distinct but partially correlated processes (Beer et al., 2007; Fatichi et al., 2014); these processes may or may not induce consistent annual changes, depending on the environmental conditions faced by trees. For F. sylvatica and temperate oaks, maximum correlation values corresponded to flux aggregation periods that were consistent with the previously reported phenology of the woody biomass increment (Table 3, Supplement S10; Michelot et al., 2012). Babst et al. (2014) and Granier et al. (2008) similarly reported close relationships between the AWBI and forest $\mathrm{C}$ fluxes that were summed until cessation of growth (August/September). The flux aggregation periods were, however, not related to the timing of wood growth in Q. ilex or P. abies (Cuny et al., 2012; Lempereur et al., 2015), which indicates that inter-annual variation in the AWBI is not always solely (or even primarily, e.g. $Q$. ilex and P. abies) dependent on the $\mathrm{C}$ derived from photosynthesis. Specifically, the agreement between the observed 

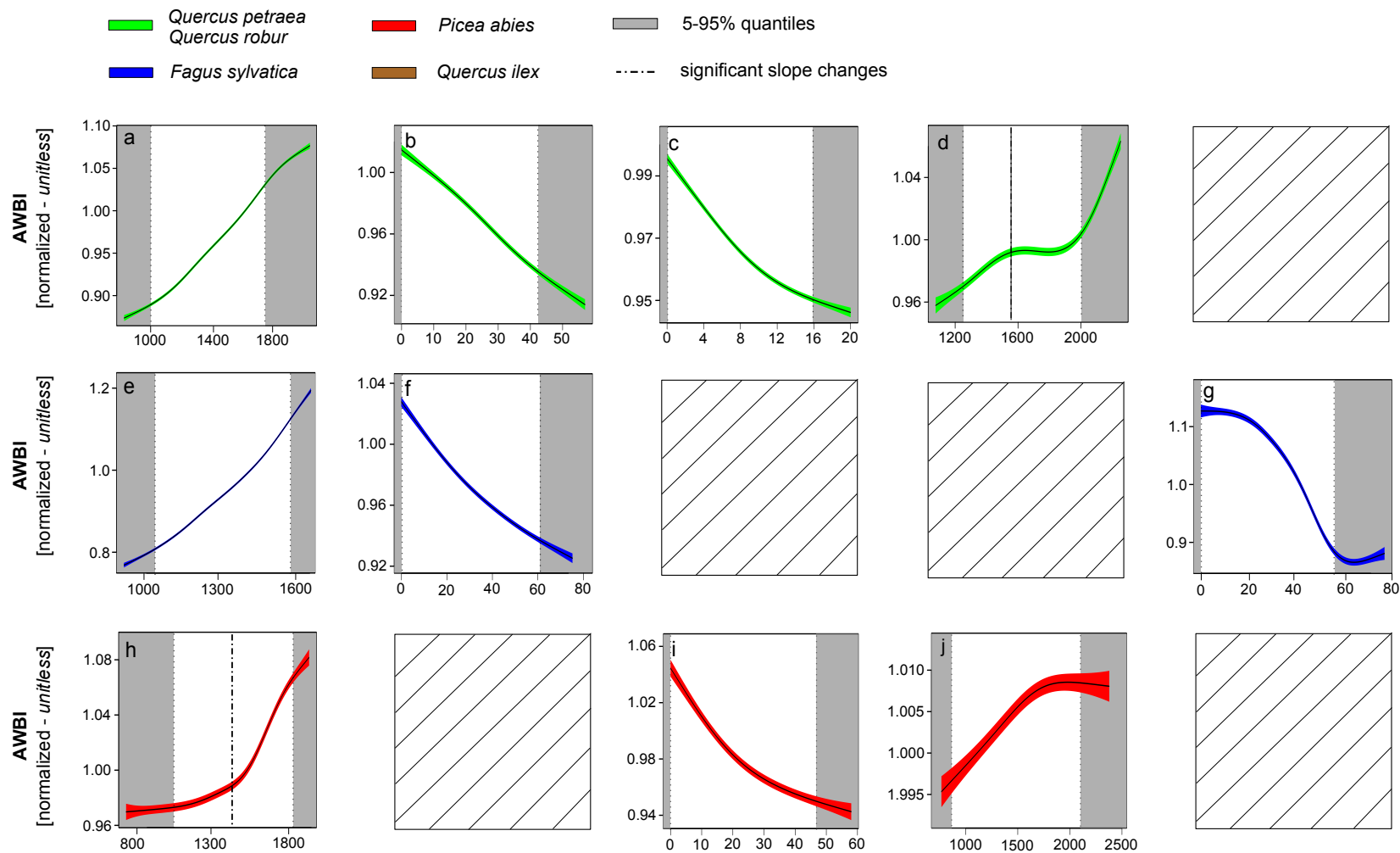

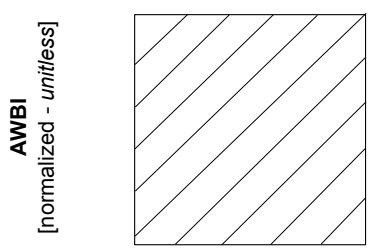

Gross primary production of the current growth period $\left[\mathrm{GPP}_{\mathrm{gp}}, \mathrm{gC} / \mathrm{m}^{2}\right]$

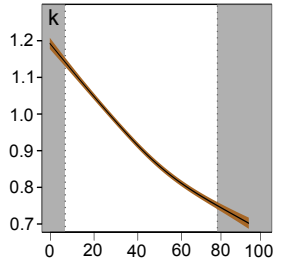

Water stress duration over the current growth period

[WS_per ${ }_{\mathrm{gp}}$, number of days]

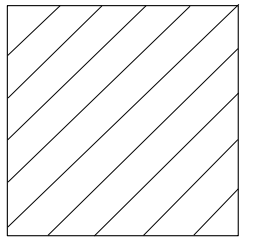

Temperature stress duration over the current growth period

[templim, number of days]

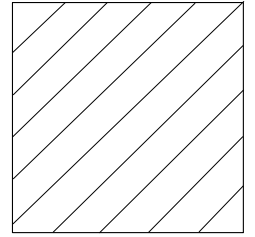

Gross primary production of the previous year $\left[\mathrm{GPP}_{\mathrm{y}-1}, \mathrm{gC} / \mathrm{m}^{2}\right]$

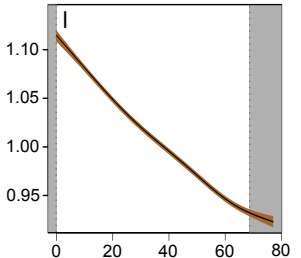

Water stress intensity index of the previous year [WS_int ${ }_{\mathrm{y}-1}$, unitless]

Figure 5. Temporal dependences of annual wood growth: marginal effects of each explanatory variable on the annual wood growth. The lines represent smoothing splines with $50 \%$ frequency response cut-offs. The coloured areas indicate the $95 \%$ confidence intervals. The 5 and $95 \%$ data quantiles (grey areas) were not considered in the discussion. The marginal effect of a given variable $X$ was obtained by fixing the value of $X$ and averaging the RF predictions over all the combinations of observed values for the other predictors in the data set (Cutler et al., 2007). The marginal predictions were collected over the entire range of $X$ in the training data using a regular grid.

annual growth and a short period of $\mathrm{C}$ flux aggregation in early summer that was reported for $Q$. ilex corresponds to the effect of growth cessation on the annual biomass increment, which has been attributed to a drought-induced limitation of cambial activity at the Puéchabon site (Lempereur et al., 2015). The processes that underlie the relationship of the long flux aggregation period and the annual biomass increment of $P$. abies may include the effect of late winter temperature on cambium phenology (Rossi et al., 2011). Overall, our results suggest that using growth-flux correlation coefficients when investigating either source limitation of growth or the seasonality of $\mathrm{C}$ allocation to woody biomass can lead to misleading conclusions.

\subsection{Between-site variability in the $\mathrm{C}$ allocation to woody biomass growth is related to ontogeny and competition intensity}

We highlighted an age-related decline in the $\mathrm{C}$ partitioning to woody biomass in all three species (Fig. 3b). This result had previously been observed in $F$. sylvatica stands using measurements of the main $\mathrm{C}$ compartments along a chronosequence (Genet et al., 2010). Several non-exclusive processes can explain this age-related trend. Increases in tree height 
are associated with increases in the hydraulic resistance of xylem, which may lead to declines in the turgor of living cells and result in potentially negative consequences on cambial activity (Woodruff et al., 2004). This constraint may result in a height-related sink limitation of growth (Woodruff and Meinzer, 2011), which is consistent with our results. Additionally, life-history traits, such as a greater emphasis on reproduction in older stands, could also be involved. However, the interactions of growth and reproductive mechanisms are still under debate (Hoch et al., 2013; Thomas, 2011) and have yet to be properly represented in TBMs. Only the GPP component of the simulated tree $\mathrm{C}$ balance was retained in the final models (Table 4), thereby indicating that an increase in maintenance respiration with greater stand biomass most likely did not contribute to the age-related decline in biomass growth (Drake et al., 2011; Tang et al., 2014). Although height-related hydraulic constraints on $\mathrm{C}$ assimilation have been suggested to be an important driver (Ryan et al., 2006; Tang et al., 2014), recent studies have suggested that changes in demography and stand structure may primarily explain the age-related decline observed in stand wood growth (Binkley et al., 2002; Xu et al., 2012). Our results suggest that changes in the $\mathrm{C}$ allocation should also be considered, because no mortality occurred in our plots during the measurement period (data not shown). We additionally identified a significantly higher $\mathrm{C}$ partitioning to woody biomass in temperate oak stands with greater competition intensity (i.e. high stand basal area, Table 3). To date, reports regarding the effect of competition on $\mathrm{C}$ allocation dynamics are conflicting (Litton et al., 2007) and suggest no significant or consistent effect. Moreover, we found no significant effect of soil nutrient availability on the $\mathrm{C}$ allocation dynamics along the studied ecological gradient, whereas a recent meta-analysis reported that this factor positively affects $\mathrm{C}$ partitioning to forest biomass on the global scale (Vicca et al., 2012). The RENECOFOR network only includes relatively fertile sites (Supplement S5), which could putatively explain the apparent tension between our results and the conclusions of the meta-analysis. Therefore, more studies are required to elucidate the contributions of the various drivers to the variation in $\mathrm{C}$ partitioning to woody biomass on scales that range from local to global.

\subsection{Inter-annual variability in woody biomass growth is consistent with combined source-sink limitations}

Water and temperature stress exerted significant direct control on the inter-annual variation of woody biomass growth (i.e. independent of their effects on $\mathrm{C}$ assimilation) for every species and biome (Table 5 and Figs. 4 and 5). Cambial growth has been reported to be inhibited at lower water stress levels than photosynthesis (Muller et al., 2011; Tardieu et al., 2011). Indeed, drought-induced decrease in cell turgor strongly affects cell divisions (Woodruff and Meinzer, 2011) and cell wall expansion (Cosgrove, 2005; Lockhart,
1965) before gas exchange modulation comes into play. Similarly, there is evidence that cell growth processes, such as cell division, are more sensitive than photosynthesis to low temperatures (Körner, 2008). Although these findings documented the plausible mechanisms of sink control of biomass growth at the cellular scale, there is still considerable debate regarding whether the sink or the $\mathrm{C}$ source actually limits the growth of the world's forests (Palacio et al., 2014; Wiley and Helliker, 2012). The typically observed large $C$ reserve pools (Hoch et al., 2003; Würth et al., 2005) have been interpreted as a consequence of an overabundant $\mathrm{C}$ supply and thus evidence of sink control of tree growth (Körner, 2003). However, recent works have suggested that a source limitation of growth may be compatible with large $\mathrm{C}$ reserve pools if part of this mobile $\mathrm{C}$ is sequestered rather than stored (Millard and Grelet, 2010) or if C storage is an active tree response to environmental stress (Dietze et al., 2014; Wiley and Helliker, 2012). Using an alternative methodology (i.e. a methodology that is not based on C storage measurement) our results suggest that sink limitation has a significant effect on the annual woody biomass growth of five species that are representative of different European biomes, including deciduous temperate forests. Because sink limitation implies that there are periods with significant $C$ supply but no growth, our results also corroborate recent empirical studies that reported a significant role of growth duration in the annual variability of tree radial increment (Brzostek et al., 2014; Cuny et al., 2012; Lempereur et al., 2015). Additionally, we observed that past environmental constraints significantly affected $\mathrm{C}$ partitioning to wood growth for each species and biome (Table 5 and Figs. 4 and 5). The lagged effect of the previous year's low $\mathrm{C}$ supply $\left(\mathrm{GPP}_{y-1}\right)$ possibly indicates a preferential $\mathrm{C}$ allocation to storage at the expense of growth in trees that face C reserve pool depletion (Bansal and Germino, 2008; Wiley et al., 2013). In support of this finding, Richardson et al. (2012) reported a strong relationship between the AWBI and the EC-based estimate of the previous year's C supply in a mature maple stand. The detrimental effect of a previous year's low C supply on temperate oak wood growth (Fig. 4) may be related to growth phenology, because this species relies on $\mathrm{C}$ reserves to achieve a large part of its annual biomass growth prior to leaf expansion in the spring (Barbaroux et al., 2003). The lagged effect of high water stress intensity on $F$. sylvatica and $Q$. ilex (Fig. 4) may be linked to previous drought-induced mortalities of buds or fine roots (Leuschner et al., 2001; López et al., 2003). Indeed, pre-built buds are thought to strongly regulate the following year's cambial activity (Delpierre et al., 2015; Palacio et al., 2012; Zweifel et al., 2006) and a recent meta-analysis concluded that $\mathrm{C}$ is preferentially allocated to fine roots at the expense of wood growth in stands that face constraining environments (Chen et al., 2013). Finally, our results suggest that $C$ supply $\left(\mathrm{GPP}_{\mathrm{gp}}\right)$ is an important driver of the annual woody biomass growth in temperate deciduous forests (Daudet et al., 2005). GPP was the component of the simulated tree $\mathrm{C}$ balance that 


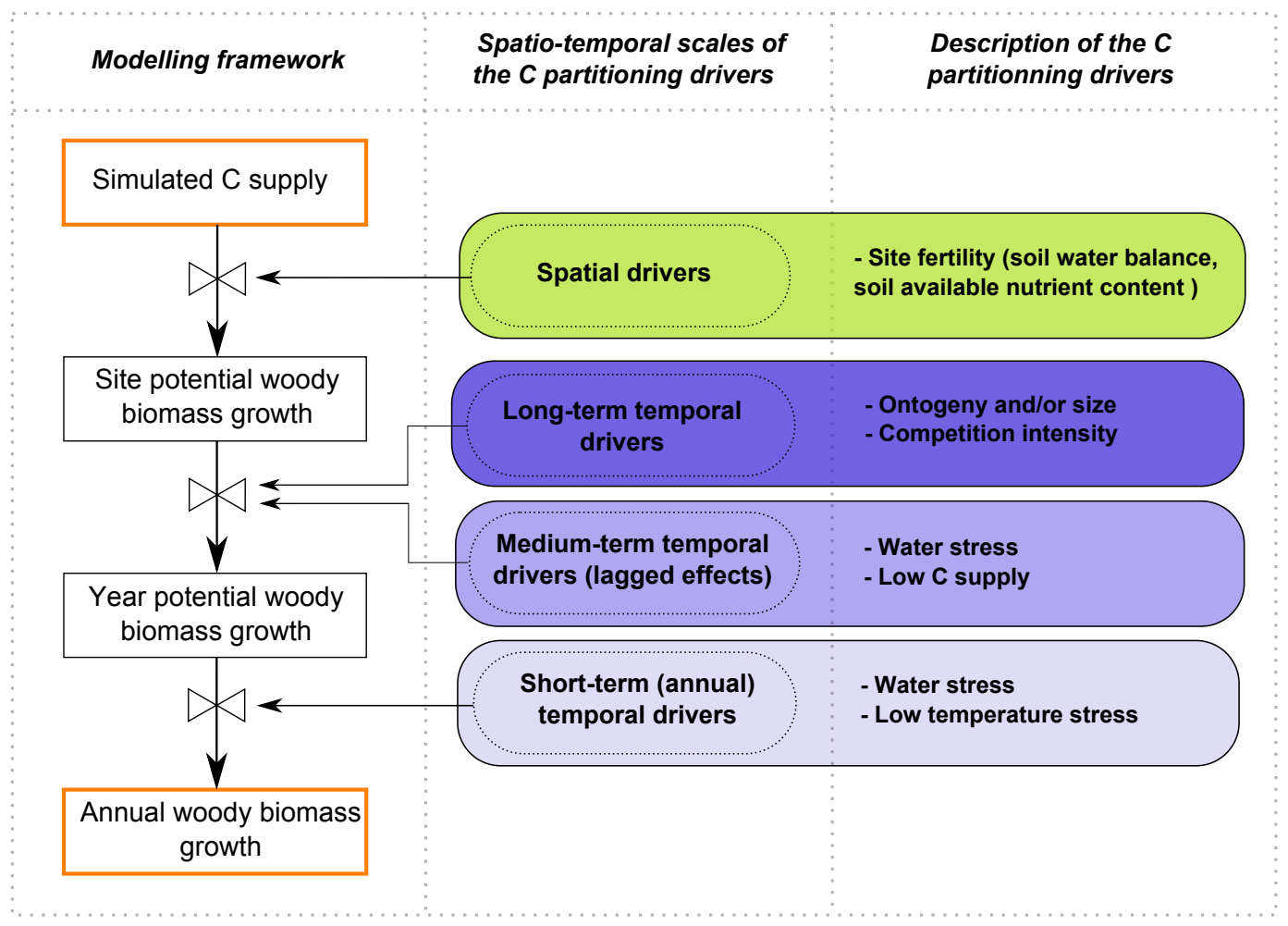

Figure 6. Modelling framework for a combined source- and sink-driven representation of C allocation to wood growth.

was most closely related to the annual variability in growth; this result indicates GPP's important role in explaining the annual variability in the net ecosystem productivity of European forests (Delpierre et al., 2012). Overall, our findings support the premise that forest woody biomass growth is subject to complex control processes that include both source and sink limitations, following Liebig's law: although numerous processes potentially influence wood growth, stand growth at a given site and a given year is predominantly limited by the most constraining factor. $\mathrm{C}$ (source) limitation of growth can thus only occur when other factors are nonlimiting (Fatichi et al., 2014), a situation that is expected to be rare in strongly constrained environment such as Mediterranean or mountainous areas (Fig. 4).

\subsection{Toward an integrated modelling framework}

Most models that are currently used to project the outcome of global changes on forests represent wood growth as a fraction of the total $\mathrm{C}$ uptake (i.e. source control of growth; De Kauwe et al., 2014). This C-centric perspective overlooks the possibility of sink control of growth and thus ignores results such as those presented in this study and those of earlier local studies (reviewed by Fatichi et al., 2014). Consequently, this perspective possibly hampers the ability of TBMs to project future forest productivity (Fatichi et al., 2014). On the basis of our analysis of the spatio-temporal dynamics of
C allocation to wood growth on a regional scale, we suggest a straightforward, combined source- and sink-driven forest growth modelling framework (Fig. 6). In this framework, a potential site-specific allocation coefficient is first defined to represent the effect of soil fertility on the $\mathrm{C}$ allocation to wood (Vicca et al., 2012). In a second step, this coefficient is adjusted to the physiological state of the stand by accounting for the dependences of the $\mathrm{C}$ allocation on ontogeny, competition intensity and lagged environmental stressors. Lagged environmental stressors are represented by a negative effect on the previous year's water stress index and low C uptake on the allocation coefficient. The resulting potential allocation coefficient is finally modulated on a daily basis by (i) the phenology of wood growth, which defines the onset and cessation of the growth period (Delpierre et al., 2015), and (ii) the sink limitations of wood growth: the coefficient value of a given day is calculated using the potential coefficient value and the water and temperature stresses experienced during that day. The water and temperature stresses induce day-today fluctuations in the allocation coefficient value that represent the sink limitations of wood growth, i.e. the direct effect of water and temperature stresses on growth. The framework presented here is a calibration strategy that requires field data to be implemented in TBMs. Our results can help in defining the forms of the coefficient dependences that will be formalized in the next generation of models (Figs. 3 and 5). 
Our approach can be seen as an intermediate step toward a more mechanistic representation of $\mathrm{C}$ allocation to woody biomass (Hölttä et al., 2010; Schiestl-Aalto et al., 2015). It synthesizes the current knowledge regarding forest growth dependences and has the potential to unify seemingly contradictory observations within a single modelling framework. The simulated growth is indeed subject to the combined controls of $\mathrm{C}$ supply and changes in $\mathrm{C}$ allocation due to endogenous adjustments and/or modulations of sink activity (Fig. 6). These controls result from distinct processes, which are independently represented in the modelling framework. The relative influences of the various processes, i.e. the simulated growth causalities, are thus likely to vary both spatially and temporally, depending on the environmental conditions faced by trees. Our approach therefore has the potential to shed light on the contrasted results reported by correlative studies. Although the value is comparable to the values of previous studies (Lebourgeois et al., 2005; Mérian et al., 2011), the proportion of the annual growth variability that was explained by our approach was moderate (Table 5). Plausible explanations for this result include (i) unreported management interventions that may have skewed the historical stand growth reconstruction and (ii) potentially important growth drivers that were not considered here, such as changes in $\mathrm{C}$ partitioning due to mast seeding (Mund et al., 2010), genetic differentiation among tree populations (Vitasse et al., 2014) or allometry-mediated tree acclimation to drought (MartinStPaul et al., 2013). A third factor that hampered the ability of our empirical models to explain the annual growth variability is the potential disagreement between the CASTANEA outputs that were used as explanatory variables and the corresponding actual drivers. Although we argued that (i) the CASTANEA model has been thoroughly validated at many EC sites from throughout Europe and (ii) the presented growth dependences demonstrated their robustness against the reported uncertainties of the CASTANEA simulations, the quality of the simulations was limited by the idiosyncrasies of the sites we examined in this study. In particular, a number of past disturbances such as insect outbreaks, windthrow or unreported commercial thinning could have temporarily induced large discrepancies between the actual and simulated C fluxes (Grote et al., 2011; Hicke et al., 2012). The error that is attributable to model performance unfortunately remains unknown because of the absence of EC measurements at our study sites (except for the Puéchabon site; see Delpierre et al., 2012). Despite this additional uncertainty, the combined use of field measurements and process-based modelling allowed us to present the first species-specific evaluation of annual $\mathrm{C}$ allocation to growth along regional environmental gradients. Our results suggest that implementing the presented $\mathrm{C}$ allocation dependences in TBMs will refine the projections of the outcome of global changes on forest growth and have implications for the predicted evolution of forest $\mathrm{C}$ sink, forest diebacks and tree species distributions (Cheaib et al., 2012).

\section{The Supplement related to this article is available online at doi:10.5194/bg-12-2773-2015-supplement.}

Acknowledgements. We wish to thank the Office National des Forêts and the RENECOFOR network team, particularly Manuel Nicolas and Marc Lanier, for providing the RENECOFOR database. The SAFRAN database was provided by Météo-France as part of the HYMEX project. J. Guillemot received a PhD grant from the French Ministère de l'Enseignement Supérieur et de la Recherche and the University of Paris-Sud. A post-doctoral research grant to N. K. Martin-StPaul was provided by the Humboldt project within GIS Climat. As part of the ICP forests network data (icp-forests.net), the material used in this article is available, free of charge, upon request (please contact $\mathrm{M}$. Nicolas, manuel.nicolas@onf.fr, +0033160 7492 28, Office National des Forêts, Fontainebleau, 77300, France).

Edited by: S. Zaehle

\section{References}

Abadie, P., Roussel, G., Dencausse, B., Bonnet, C., Bertocchi, E., Louvet, J., Kremer, A., and Garnier-Géré, P.: Strength, diversity and plasticity of postmating reproductive barriers between two hybridizing oak species (Quercus robur L. and Quercus petraea (Matt) Liebl.), J. Evol. Biol., 25, 157-173, 2012.

Archer, K. J. and Kimes, R. V: Empirical characterization of random forest variable importance measures, Comput. Stat. Data Anal., 52, 2249-2260, 2008.

Babst, F., Bouriaud, O., Papale, D., Gielen, B., Janssens, I. A., Nikinmaa, E., Ibrom, A., Wu, J., Bernhofer, C., Köstner, B., Grünwald, T., Seufert, G., Ciais, P., and Frank, D.: Above-ground woody carbon sequestration measured from tree rings is coherent with net ecosystem productivity at five eddy-covariance sites, New Phytol., 201, 1289-1303, 2014.

Bansal, S. and Germino, M. J.: Carbon balance of conifer seedlings at timberline: relative changes in uptake, storage, and utilization, Oecologia, 158, 217-27, 2008.

Barbaroux, C., Breda, N., and Dufrene, E.: Distribution of aboveground and below-ground carbohydrate reserves in adult trees of two contrasting broad-leaved species (Quercus petraea and Fagus sylvatica), New Phytol., 157, 605-615, 2003.

Barton, K. and Barton, M. K.: Package "MuMIn," Version, 1, 1-57, 2014.

Bates, D., Sarkar, D., Bates, M. D., and Matrix, L.: The lme4 package, R Packag. version, 2, 1-29, 2007.

Beer, C., Reichstein, M., Ciais, P., Farquhar, G. D., and Papale, D.: Mean annual GPP of Europe derived from its water balance, Geophys. Res. Lett., 34, 1-4, 2007.

Binkley, D., Stape, J. L., Ryan, M. G., Barnard, H. R., and Fownes, J.: Age-related Decline in Forest Ecosystem Growth: An Individual-Tree, Stand-Structure Hypothesis, Ecosystems, 5, 58-67, 2002.

Bontemps, J.-D., Hervé, J.-C., and Dhôte, J.-F.: Long-term changes in forest productivity: a consistent assessment in even-aged stands, For. Sci., 55, 549-564, 2009. 
Bontemps, J.-D., Herve, J.-C., Duplat, P., and Dhôte, J.-F.: Shifts in the height-related competitiveness of tree species following recent climate warming and implications for tree community composition: the case of common beech and sessile oak as predominant broadleaved species in Europe, Oikos, 121, 1287-1299, 2012.

Bouriaud, O., Bréda, N., Le Moguédec, G., and Nepveu, G.: Modelling variability of wood density in beech as affected by ring age, radial growth and climate, Trees-Struct. Funct., 18, 264276, 2004.

Breiman, L.: Random forests, Mach. Learn., 45, 5-32, 2001.

Brêthes, A. and Ulrich, E.: RENECOFOR - Caractéristiques pédologiques des 102 peuplements du réseau., Off. Natl. des forêts, Département des Rech. Tech., 1997.

Brüggemann, N., Gessler, a., Kayler, Z., Keel, S. G., Badeck, F., Barthel, M., Boeckx, P., Buchmann, N., Brugnoli, E., Esperschütz, J., Gavrichkova, O., Ghashghaie, J., Gomez-Casanovas, N., Keitel, C., Knohl, a., Kuptz, D., Palacio, S., Salmon, Y., Uchida, Y., and Bahn, M.: Carbon allocation and carbon isotope fluxes in the plant-soil-atmosphere continuum: a review, Biogeosciences, 8, 3457-3489, doi:10.5194/bg-8-3457-2011, 2011.

Brzostek, E. R., Dragoni, D., Schmid, H. P., Rahman, a F., Sims, D., Wayson, C. a, Johnson, D. J., and Phillips, R. P.: Chronic water stress reduces tree growth and the carbon sink of deciduous hardwood forests., Glob. Chang. Biol., 20, 8, doi:10.1111/gcb.12528, 2014.

Burnham, K. P. and Anderson, D. R.: Model selection and multimodel inference: a practical information-theoretic approach, Springer, 2002.

Carnicer, J., Barbeta, A., Sperlich, D., Coll, M., and Peñuelas, J.: Contrasting trait syndromes in angiosperms and conifers are associated with different responses of tree growth to temperature on a large scale, Front. Plant Sci., 4, 409, doi:10.3389/fpls.2013.00409, 2013.

Carvalhais, N., Forkel, M., Khomik, M., Bellarby, J., Jung, M., Migliavacca, M., Mu, M., Saatchi, S., Santoro, M., and Thurner, M.: Global covariation of carbon turnover times with climate in terrestrial ecosystems, Nature, 514, 213-217, 2014.

Chapin, F. S., Schulze, E.-D., and Mooney, H. A.: The ecology and economics of storage in plants, Annu. Rev. Ecol. Syst., 21, 423447, 1990.

Cheaib, A., Badeau, V., Boe, J., Chuine, I., Delire, C., Dufrêne, E., François, C., Gritti, E. S., Legay, M., Pagé, C., Thuiller, W., Viovy, N., and Leadley, P.: Climate change impacts on tree ranges: model intercomparison facilitates understanding and quantification of uncertainty., Ecol. Lett., 15, 533-44, 2012.

Chen, G., Yang, Y., and Robinson, D.: Allocation of gross primary production in forest ecosystems: allometric constraints and environmental responses, New Phytol., 200, 1176-1186, 2013.

Chernick, M. R.: Bootstrap methods: A guide for practitioners and researchers, Wiley, 2011.

Clark, D. B., Mercado, L. M., Sitch, S., Jones, C. D., Gedney, N., Best, M. J., Pryor, M., Rooney, G. G., Essery, R. L. H., Blyth, E., Boucher, O., Harding, R. J., Huntingford, C., and Cox, P. M.: The Joint UK Land Environment Simulator (JULES), model description - Part 2: Carbon fluxes and vegetation dynamics, Geosci. Model Dev., 4, 701-722, doi:10.5194/gmd-4-701-2011, 2011.

Cluzeau, C., Ulrich, E., Lanier, M., and Garnier, F.: RENECOFOR - Interprétation des mesures dendrométriques de 1991 à 1995 des
102 peuplements du réseau, Off. Natl. des forêts, Département des Rech. Tech., 322 pp., 1998.

Cosgrove, D. J.: Growth of the plant cell wall, Nat. Rev. Mol. Cell Biol., 6, 850-61, doi:10.1038/nrm1746, 2005.

Croisé, L., Cluzeau, C., Ulrich, E., Lanier, M., and Gomez, A.: RENECOFOR - Interprétation des analyses foliaires réalisées dans les 102 peuplements du réseau de 1993 a 1997 et premières évaluations interdisciplinaires, Off. Natl. des forêts, Département des Rech. Tech., 428 pp., 1999.

Cuny, H. E., Rathgeber, C. B. K., Lebourgeois, F., Fortin, M., and Fournier, M.: Life strategies in intra-annual dynamics of wood formation: example of three conifer species in a temperate forest in north-east France, Tree Physiol., 32, 612-625, 2012.

Cutler, D. R., Edwards, T. C., Beard, K. H., Cutler, A., and Hess, K. T.: Random forests for classification in ecology, Ecology, 88, 2783-2792, 2007.

Daudet, F.-A., Améglio, T., Cochard, H., Archilla, O., and Lacointe, A.: Experimental analysis of the role of water and carbon in tree stem diameter variations, J. Exp. Bot., 56, 135-144, 2005.

David, A.: Modélisation de la croissance ligneuse chez le Hêtre et le Chêne sessile. Master's thesis dissertation, Université Paris-Sud, Orsay, 2011.

Davi, H., Dufrêne, E., Granier, a., Le Dantec, V., Barbaroux, C., François, C., and Bréda, N.: Modelling carbon and water cycles in a beech forest, Ecol. Modell., 185, 387-405, 2005.

Davi, H., Barbaroux, C., Francois, C., and Dufrene, E.: The fundamental role of reserves and hydraulic constraints in predicting LAI and carbon allocation in forests, Agric. For. Meteorol., 149, 349-361, 2009.

De Kauwe, M. G., Medlyn, B. E., Zaehle, S., Walker, A. P., Dietze, M. C., Wang, Y., Luo, Y., Jain, A. K., El-Masri, B., and Hickler, T.: Where does the carbon go?, A model-data intercomparison of vegetation carbon allocation and turnover processes at two temperate forest free-air $\mathrm{CO}_{2}$ enrichment sites, New Phytol., 203, 883-899, doi:10.1111/nph.12847, 2014.

Deleuze, C., Pain, O., Dhôte, J. F., and Hervé, J. C.: A flexible radial increment model for individual trees in pure even-aged stands, Ann. For. Sci., 61, 327-335, 2004.

Delpierre, N., Soudani, K., François, C., Köstner, B., Pontailler, J.-Y., Nikinmaa, E., Misson, L., Aubinet, M., Bernhofer, C., Granier, a., Grünwald, T., Heinesch, B., Longdoz, B., Ourcival, J.-M., Rambal, S., Vesala, T., and Dufrêne, E.: Exceptional carbon uptake in European forests during the warm spring of 2007: a data-model analysis, Glob. Chang. Biol., 15, 1455-1474, 2009.

Delpierre, N., Soudani, K., François, C., Le Maire, G., Bernhofer, C., Kutsch, W., Misson, L., Rambal, S., Vesala, T., and Dufrêne, E.: Quantifying the influence of climate and biological drivers on the interannual variability of carbon exchanges in European forests through process-based modelling, Agric. For. Meteorol., 154/155, 99-112, 2012.

Delpierre, N., Vitasse, Y., Chuine, I., Guillemot, J., Bazot, S., Rutishauser, T., and Rathgeber, C. B. K.: Temperate and boreal forest tree phenology: from organ-scale processes to terrestrial ecosystem models, Ann. For. Sci., in press, doi:10.1007/s13595015-0477-6, 2015.

Dhôte, J.-F. and Hercé, É. de: Un modèle hyperbolique pour l'ajustement de faisceaux de courbes hauteur-diamètre, Can. J. For. Res., 24, 1782-1790, 1994. 
Dietze, M. C., Sala, A., Carbone, M. S., Czimczik, C. I., Mantooth, J. A., Richardson, A. D., and Vargas, R.: Nonstructural Carbon in Woody Plants, Annu. Rev. Plant Biol., 65, 667-687, 2014.

Dormann, C. F., Elith, J., Bacher, S., Buchmann, C., Carl, G., Carré, G., Marquéz, J. R. G., Gruber, B., Lafourcade, B., and Leitão, P. J.: Collinearity: a review of methods to deal with it and a simulation study evaluating their performance, Ecography (Cop.)., 36, 27-46, 2013.

Drake, J. E., Davis, S. C., Raetz, L. M., and DeLucia, E. H.: Mechanisms of age-related changes in forest production: the influence of physiological and successional changes, Glob. Chang. Biol., 17, 1522-1535, 2011.

Drobyshev, I., Gewehr, S., Berninger, F., and Bergeron, Y.: Species specific growth responses of black spruce and trembling aspen may enhance resilience of boreal forest to climate change, J. Ecol., 101, 231-242, 2013.

Dufrêne, E., Davi, H., Francois, C., Le Maire, G., Le Dantec, V., and Granier, A.: Modelling carbon and water cycles in a Beech forest - Part I: Model description and uncertainty analysis on modelled NEE, Ecol. Modell., 185, 407-436, 2005.

Fatichi, S., Leuzinger, S., and Körner, C.: Moving beyond photosynthesis: from carbon source to sink-driven vegetation modeling, New Phytol., 201, 1086-1095, doi:10.1111/nph.12614, 2014.

Franklin, O., Johansson, J., Dewar, R. C., Dieckmann, U., McMurtrie, R. E., Brännström, ̊., and Dybzinski, R.: Modeling carbon allocation in trees: a search for principles, Tree Physiol., 32, 648666, 2012

Friend, A. D., Lucht, W., Rademacher, T. T., Keribin, R., Betts, R., Cadule, P., Ciais, P., Clark, D. B., Dankers, R., Falloon, P. D., Ito, A., Kahana, R., Kleidon, A., Lomas, M. R., Nishina, K., Ostberg, S., Pavlick, R., Peylin, P., Schaphoff, S., Vuichard, N., Warszawski, L., Wiltshire, A., and Woodward, F. I.: Carbon residence time dominates uncertainty in terrestrial vegetation responses to future climate and atmospheric $\mathrm{CO}_{2}$, Proc. Natl. Acad. Sci., 111, 9, doi:10.1073/pnas.1222477110, 2013.

Gaucherel, C., Guiot, J., and Misson, L.: Changes of the potential distribution area of French Mediterranean forests under global warming, Biogeosciences, 5, 1493-1504, doi:10.5194/bg5-1493-2008, 2008.

Genet, H., Bréda, N., and Dufrêne, E.: Age-related variation in carbon allocation at tree and stand scales in beech (Fagus sylvatica L.) and sessile oak (Quercus petraea (Matt.) Liebl.) using a chronosequence approach., Tree Physiol., 30, 177-92, doi:10.1093/treephys/tpp105, 2010.

Genuer, R., Poggi, J.-M., and Tuleau-Malot, C.: Variable selection using random forests, Pattern Recognit. Lett., 31, 2225-2236, 2010.

Gielen, B., De Vos, B., Campioli, M., Neirynck, J., Papale, D., Verstraeten, a., Ceulemans, R., and Janssens, I. a.: Biometric and eddy covariance-based assessment of decadal carbon sequestration of a temperate Scots pine forest, Agric. For. Meteorol., 174/175, 135-143, 2013.

Gough, C. M., Flower, C. E., Vogel, C. S., Dragoni, D., and Curtis, P. S.: Whole-ecosystem labile carbon production in a north temperate deciduous forest, Agric. For. Meteorol., 149, 1531-1540, 2009.

Graham, M. H.: Confronting multicollinearity in ecological multiple regression, Ecology, 84, 2809-2815, 2003.
Granier, A., Bréda, N., Biron, P., and Villette, S.: A lumped water balance model to evaluate duration and intensity of drought constraints in forest stands, Ecol. Modell., 116, 269-283, 1999.

Granier, A., Bréda, N., Longdoz, B., Gross, P., and Ngao, J.: Ten years of fluxes and stand growth in a young beech forest at Hesse, North-eastern France, Ann. For. Sci., 64, 704-704, 2008.

Grote, R., Kiese, R., Grünwald, T., Ourcival, J.-M., and Granier, A. Modelling forest carbon balances considering tree mortality and removal, Agric. For. Meteorol., 151, 179-190, 2011.

Guillemot, J., Delpierre, N., Vallet, P., François, C., Martin-StPaul, N. K., Soudani, K., Nicolas, M., Badeau, V., and Dufrêne, E.: Assessing the effects of management on forest growth across France: insights from a new functional-structural model, Ann. Bot., 114, 779-793, 2014.

Hicke, J. A., Allen, C. D., Desai, A. R., Dietze, M. C., Hall, R. J., Kashian, D. M., Moore, D., Raffa, K. F., Sturrock, R. N., and Vogelmann, J.: Effects of biotic disturbances on forest carbon cycling in the United States and Canada, Glob. Chang. Biol., 18, 7-34, 2012.

Hoch, G., Richter, A., and Körner, C.: Non-structural carbon compounds in temperate forest trees, Plant. Cell Environ., 26, 10671081, 2003.

Hoch, G., Siegwolf, R. T. W., Keel, S. G., Körner, C., and Han, Q.: Fruit production in three masting tree species does not rely on stored carbon reserves., Oecologia, 171, 653-62, 2013.

Hölttä, T., Mäkinen, H., Nöjd, P., Mäkelä, A., and Nikinmaa, E.: A physiological model of softwood cambial growth, Tree Physiol., 30, 1235-52, 2010.

Keenan, T. F., Baker, I., Barr, A., Ciais, P., Davis, K., Dietze, M., Dragoni, D., Gough, C. M., Grant, R., and Hollinger, D.: Terrestrial biosphere model performance for inter-annual variability of land-atmosphere $\mathrm{CO}_{2}$ exchange, Glob. Chang. Biol., 18, 19711987, 2012.

Keyes, M. R. and Grier, C. C.: Above- and below-ground net production in 40-year-old Douglas-fir stands on low and high productivity sites, Can. J. For. Res., 11, 599-605, 1981.

Körner, C.: Carbon limitation in trees, J. Ecol., 91, 4-17, 2003.

Körner, C.: Winter crop growth at low temperature may hold the answer for alpine treeline formation, Plant Ecol. Divers., 1, 3$11,2008$.

Krinner, G., Viovy, N., de Noblet-Ducoudré, N., Ogée, J., Polcher, J., Friedlingstein, P., Ciais, P., Sitch, S., and Prentice, I. C.: A dynamic global vegetation model for studies of the coupled atmosphere-biosphere system, Global Biogeochem. Cy., 19, 14, 2005.

Kudo, K., Nabeshima, E., Begum, S., Yamagishi, Y., Nakaba, S., Oribe, Y., Yasue, K., and Funada, R.: The effects of localized heating and disbudding on cambial reactivation and formation of earlywood vessels in seedlings of the deciduous ring-porous hardwood, Quercus serrata, Ann. Bot., 113, 1021-1027, 2014.

Kunstler, G., Albert, C. H., Courbaud, B., Lavergne, S., Thuiller, W., Vieilledent, G., Zimmermann, N. E., and Coomes, D. A.: Effects of competition on tree radial-growth vary in importance but not in intensity along climatic gradients, J. Ecol., 99, 300312, 2011.

Lebourgeois, F.: RENECOFOR - Etude dendrochronologique des 102 peuplements du réseau, Off. Natl. des forêts, Département des Rech. Tech., 368 pp., 1997. 
Lebourgeois, F., Bréda, N., Ulrich, E., and Granier, A.: Climatetree-growth relationships of European beech (Fagus sylvatica L.) in the French Permanent Plot Network (RENECOFOR), Trees, 19, 385-401, 2005.

Lempereur, M., Martin-StPaul, N. K., Damesin, C., Joffre, R., Ourcival, J. M., Rocheteau, A., and Rambal, S.: Growth duration is a better predictor of stem increment than carbon supply in a Mediterranean oak forest: implications for assessing forest productivity under climate change, New Phytol., in press, doi:10.1111/nph.13400, 2015.

Leuschner, C., Backes, K., Hertel, D., Schipka, F., Schmitt, U., Terborg, O., and Runge, M.: Drought responses at leaf, stem and fine root levels of competitive Fagus sylvatica L. and Quercus petraea (Matt.) Liebl. trees in dry and wet years, For. Ecol. Manage., 149, 33-46, 2001.

Leuzinger, S. and Hättenschwiler, S.: Beyond global change: lessons from 25 years of $\mathrm{CO}_{2}$ research, Oecologia, 171, 639-51, 2013.

Leuzinger, S., Manusch, C., Bugmann, H., and Wolf, A.: A sinklimited growth model improves biomass estimation along boreal and alpine tree lines, Glob. Ecol. Biogeogr., 22, 924-932, 2013.

Liaw, A. and Wiener, M.: The randomforest package, R News, 2, 18-22, 2002.

Litton, C. M., Raich, J. W., and Ryan, M. G.: Carbon allocation in forest ecosystems, Glob. Chang. Biol., 13, 2089-2109, 2007.

Lockhart, J. A.: An analysis of irreversible plant cell elongation, J. Theor. Biol., 8, 264-275, 1965.

López, B. C., Sabate, S., and Gracia, C. A.: Thinning effects on carbon allocation to fine roots in a Quercus ilex forest, Tree Physiol., 23, 1217-1224, 2003.

Lupi, C., Morin, H., Deslauriers, A., and Rossi, S.: Xylem phenology and wood production: resolving the chicken-or-egg dilemma, Plant. Cell Environ., 33, 1721-30, 2010.

Luyssaert, S., Inglima, I., Jung, M., Richardson, a. D., Reichstein, M., Papale, D., Piao, S. L., Schulze, E.-D., Wingate, L., Matteucci, G., Aragao, L., Aubinet, M., Beer, C., Bernhofer, C., Black, K. G., Bonal, D., Bonnefond, J.-M., Chambers, J., Ciais, P., Cook, B., Davis, K. J., Dolman, a. J., Gielen, B., Goulden, M., Grace, J., Granier, A., Grelle, A., Griffis, T., Grünwald, T., Guidolotti, G., Hanson, P. J., Harding, R., Hollinger, D. Y., Hutyra, L. R., Kolari, P., Kruijt, B., Kutsch, W., Lagergren, F., Laurila, T., Law, B. E., Le Maire, G., Lindroth, A., Loustau, D., Malhi, Y., Mateus, J., Migliavacca, M., Misson, L., Montagnani, L., Moncrieff, J., Moors, E., Munger, J. W., Nikinmaa, E., Ollinger, S. V., Pita, G., Rebmann, C., Roupsard, O., Saigusa, N., Sanz, M. J., Seufert, G., Sierra, C., Smith, M.-L., Tang, J., Valentini, R., Vesala, T., and Janssens, I. A.: $\mathrm{CO}_{2}$ balance of boreal, temperate, and tropical forests derived from a global database, Glob. Chang. Biol., 13, 2509-2537, 2007.

Magnani, F., Mencuccini, M., and Grace, J.: Age-related decline in stand productivity: the role of structural acclimation under hydraulic constraints, Plant. Cell Environ., 23, 251-263, 2000.

Martin-StPaul, N. K., Limousin, J.-M., Vogt-Schilb, H., RodríguezCalcerrada, J., Rambal, S., Longepierre, D., and Misson, L.: The temporal response to drought in a Mediterranean evergreen tree: comparing a regional precipitation gradient and a throughfall exclusion experiment., Glob. Chang. Biol., 19, 2413-2426, 2013.

Mérian, P., Bontemps, J.-D., Bergès, L., and Lebourgeois, F.: Spatial variation and temporal instability in climate-growth relationships of sessile oak (Quercus petraea [Matt.] Liebl.) under temperate conditions, Plant Ecol., 212, 1855-1871, 2011.

Michelot, A., Simard, S., Rathgeber, C., Dufrêne, E., and Damesin, C.: Comparing the intra-annual wood formation of three $\mathrm{Eu}-$ ropean species (Fagus sylvatica, Quercus petraea and Pinus sylvestris) as related to leaf phenology and non-structural carbohydrate dynamics, Tree Physiol., 32, 1033-45, 2012.

Millard, P. and Grelet, G.-A.: Nitrogen storage and remobilization by trees: ecophysiological relevance in a changing world, Tree Physiol., 30, 1083-95, 2010.

Muller, B., Pantin, F., Génard, M., Turc, O., Freixes, S., Piques, M., and Gibon, Y.: Water deficits uncouple growth from photosynthesis, increase $\mathrm{C}$ content, and modify the relationships between $\mathrm{C}$ and growth in sink organs., J. Exp. Bot., 62, 1715-1729, 2011.

Mund, M., Kutsch, W. L., Wirth, C., Kahl, T., Knohl, a, Skomarkova, M. V., and Schulze, E.-D.: The influence of climate and fructification on the inter-annual variability of stem growth and net primary productivity in an old-growth, mixed beech forest, Tree Physiol., 30, 689-704, 2010.

Ohtsuka, T., Saigusa, N., and Koizumi, H.: On linking multiyear biometric measurements of tree growth with eddy covariancebased net ecosystem production, Glob. Chang. Biol., 15, 10151024, 2009.

Palacio, S., Hernández, R., Maestro-Martínez, M., and Camarero, J. J.: Fast replenishment of initial carbon stores after defoliation by the pine processionary moth and its relationship to the re-growth ability of trees, Trees, 26, 1627-1640, 2012.

Palacio, S., Hoch, G., Sala, A., Körner, C., and Millard, P.: Does carbon storage limit tree growth?, New Phytol., 201, 1096-1100, 2014.

Pan, Y., Birdsey, R. a, Fang, J., Houghton, R., Kauppi, P. E., Kurz, W. a, Phillips, O. L., Shvidenko, A., Lewis, S. L., Canadell, J. G., Ciais, P., Jackson, R. B., Pacala, S. W., McGuire, a D., Piao, S., Rautiainen, A., Sitch, S., and Hayes, D.: A large and persistent carbon sink in the world's forests, Science, 333, 988-993, 2011.

Pasquet, K.: Determination des chuttes de littières sur le réseau RENECOFOR de 1995 à 2002, Off. Natl. des forêts, Département des Rech. Tech., 356 pp., 2002.

Peichl, M., Brodeur, J. J., Khomik, M., and Arain, M. A.: Biometric and eddy-covariance based estimates of carbon fluxes in an agesequence of temperate pine forests, Agric. For. Meteorol., 150, 952-965, 2010.

Ponette, Q.: Chimie des sols dans les 102 peuplements du réseau, Office National des Forêts-Direction Technique, 337 pp., 1997.

Rambal, S., Joffre, R., Ourcival, J. M., Cavender-Bares, J., and Rocheteau, A.: The growth respiration component in eddy $\mathrm{CO}_{2}$ flux from a Quercus ilex mediterranean forest, Glob. Chang. Biol., 10, 1460-1469, 2004.

Richardson, A. D., Carbone, M. S., Keenan, T. F., Czimczik, C. I., Hollinger, D. Y., Murakami, P., Schaberg, P. G., and Xu, X.: Seasonal dynamics and age of stemwood nonstructural carbohydrates in temperate forest trees, New Phytol., 197, 850-861, 2013.

Rocha, A. V., Goulden, M. L., Dunn, A. L., and Wofsy, S. C.: On linking interannual tree ring variability with observations of whole-forest $\mathrm{CO}_{2}$ flux, Glob. Chang. Biol., 12, 1378-1389, 2006. 
Rossi, S., Morin, H., Deslauriers, A., and Plourde, P.-Y.: Predicting xylem phenology in black spruce under climate warming, Glob. Chang. Biol., 17, 614-625, 2011.

Rossi, S., Anfodillo, T., Cufar, K., Cuny, H. E., Deslauriers, A., Fonti, P., Frank, D., Gricar, J., Gruber, A., King, G. M., Krause, C., Morin, H., Oberhuber, W., Prislan, P., and Rathgeber, C. B. K.: A meta-analysis of cambium phenology and growth: linear and non-linear patterns in conifers of the northern hemisphere., Ann. Bot., 112, 1911-20, 2013.

Ryan, M. G., Phillips, N., and Bond, B. J.: The hydraulic limitation hypothesis revisited, Plant Cell Environ., 29, 367-81, 2006.

Sala, A., Woodruff, D. R., and Meinzer, F. C.: Carbon dynamics in trees: feast or famine?, Tree Physiol., 32, 1-12, 2012.

Schiestl-Aalto, P., Kulmala, L., Mäkinen, H., Nikinmaa, E., and Mäkelä, A.: CASSIA-a dynamic model for predicting intraannual sink demand and interannual growth variation in Scots pine, New Phytol., 206, 647-659, doi:10.1111/nph.13275, 2015.

Seynave, I., Gégout, J., Hervé, J., Drapier, J., Bruno, É., and Dumé, G.: Picea abies site index prediction by environmental factors and understorey vegetation?: a two-scale approach based on survey databases, 1678, 1669-1678, 2005.

Sitch, S., Smith, B., Prentice, I. C., Arneth, A., Bondeau, A., Cramer, W., Kaplan, J. O., Levis, S., Lucht, W., and Sykes, M. T.: Evaluation of ecosystem dynamics, plant geography and terrestrial carbon cycling in the LPJ dynamic global vegetation model, Glob. Chang. Biol., 9, 161-185, 2003.

Tang, J., Luyssaert, S., Richardson, A. D., Kutsch, W., and Janssens, I. A.: Steeper declines in forest photosynthesis than respiration explain age-driven decreases in forest growth, Proc. Natl. Acad. Sci., 111, 24, doi:10.1073/pnas.1320761111, 2014.

Tardieu, F., Granier, C., and Muller, B.: Water deficit and growth. Co-ordinating processes without an orchestrator?, Curr. Opin. Plant Biol., 14, 283-289, 2011.

Thomas, S. C.: Age-related changes in tree growth and functional biology: the role of reproduction, in Size-and age-related changes in tree structure and function, Springer, 33-64, 2011.

Ulrich, E.: Organization of forest system monitoring in France-the RENECOFOR network, in World Forestry Congress, Antalya, TR, 1997.

Vallet, P., Dhôte, J.-F., Moguédec, G. Le, Ravart, M., and Pignard, G.: Development of total aboveground volume equations for seven important forest tree species in France, For. Ecol. Manage., 229, 98-110, 2006.

Vicca, S., Luyssaert, S., Peñuelas, J., Campioli, M., Chapin, F. S., Ciais, P., Heinemeyer, a, Högberg, P., Kutsch, W. L., Law, B. E., Malhi, Y., Papale, D., Piao, S. L., Reichstein, M., Schulze, E. D., and Janssens, I. A.: Fertile forests produce biomass more efficiently., Ecol. Lett., 15, 520-526, 2012.

Vidal, J.-P., Martin, E., Franchistéguy, L., Baillon, M., and Soubeyroux, J.-M.: A 50-year high-resolution atmospheric reanalysis over France with the Safran system, Int. J. Climatol., 30, 16271644, 2010.
Vitasse, Y., Lenz, A., Kollas, C., Randin, C. F., Hoch, G., and Körner, C.: Genetic vs. non-genetic responses of leaf morphology and growth to elevation in temperate tree species, Funct. Ecol., 28, 243-252, 2014.

Wiley, E. and Helliker, B.: A re-evaluation of carbon storage in trees lends greater support for carbon limitation to growth, New Phytol., 195, 285-289, 2012.

Wiley, E., Huepenbecker, S., Casper, B. B., and Helliker, B. R.: The effects of defoliation on carbon allocation: can carbon limitation reduce growth in favour of storage?, Tree Physiol., 33, 12161228, 2013.

Wilhelmsson, L., Arlinger, J., Spångberg, K., Lundqvist, S.-O., Grahn, T., Hedenberg, Ö., and Olsson, L.: Models for Predicting Wood Properties in Stems of Picea abies and Pinus sylvestris in Sweden, Scand. J. For. Res., 17, 330-350, 2002.

Wolf, A., Field, C. B., and Berry, J. A.: Allometric growth and allocation in forests: a perspective from FLUXNET, Ecol. Appl., 21, 1546-1556, 2011.

Woodruff, D. R. and Meinzer, F. C.: Size-dependent changes in biophysical control of tree growth: the role of turgor, in Size-and age-related changes in tree structure and function, Springer, 363384, 2011.

Woodruff, D. R., Bond, B. J., and Meinzer, F. C.: Does turgor limit growth in tall trees?, Plant. Cell Environ., 27, 229-236, 2004.

Würth, M. K. R., Peláez-Riedl, S., Wright, S. J., and Körner, C. Non-structural carbohydrate pools in a tropical forest, Oecologia, 143, 11-24, 2005.

Xu, C., Turnbull, M. H., Tissue, D. T., Lewis, J. D., Carson, R., Schuster, W. S. F., Whitehead, D., Walcroft, A. S., Li, J., and Griffin, K. L.: Age-related decline of stand biomass accumulation is primarily due to mortality and not to reduction in NPP associated with individual tree physiology, tree growth or stand structure in a Quercus-dominated forest, J. Ecol., 100, 428-440, 2012.

Zha, T. S., Barr, a. G., Bernier, P.-Y., Lavigne, M. B., Trofymow, J. a., Amiro, B. D., Arain, M. a., Bhatti, J. S., Black, T. a., Margolis, H. a., McCaughey, J. H., Xing, Z. S., Van Rees, K. C. J., and Coursolle, C.: Gross and aboveground net primary production at Canadian forest carbon flux sites, Agric. For. Meteorol., 174/175, 54-64, 2013.

Zhang, S.-Y., Owoundi, R. E., Nepveu, G., Mothe, F., and Dhôte, J.-F.: Modelling wood density in European oak (Quercuspetraea and Quercusrobur) and simulating the silvicultural influence, Can. J. For. Res., 23, 2587-2593, 1993.

Zweifel, R., Zimmermann, L., Zeugin, F., and Newbery, D. M.: Intra-annual radial growth and water relations of trees: implications towards a growth mechanism., J. Exp. Bot., 57, 1445-59, 2006.

Zweifel, R., Eugster, W., Etzold, S., Dobbertin, M., Buchmann, N., and Häsler, R.: Link between continuous stem radius changes and net ecosystem productivity of a subalpine Norway spruce forest in the Swiss Alps, New Phytol., 187, 819-830, 2010. 